\title{
Twin-Screw Extrusion Processing of Rainbow trout (Oncorhynchus mykiss) Feeds Using Graded Levels of High Protein Corn-Based Distillers Dried Grains (HP-DDG) and Conventional Distillers Dried Grains with Solubles (DDGS)
}

\author{
Parisa Fallahi ${ }^{1}$, Kurt A. Rosentrater ${ }^{2}$, Kasiviswanathan Muthukumarappan ${ }^{1} \&$ Michael L. Brown $^{1}$ \\ ${ }^{1}$ Department of Agricultural and Biosystems Engineering, South Dakota State University, USA \\ ${ }^{2}$ Department of Agricultural and Biosystems Engineering, Iowa State University, Ames, IA, USA \\ Correspondence: Kurt A. Rosentrater, Department of Agricultural and Biosystems Engineering, Iowa State \\ University, Ames, IA 50011, USA. Tel: 1-515-294-4019. E-mail: karosent@iastate.edu
}

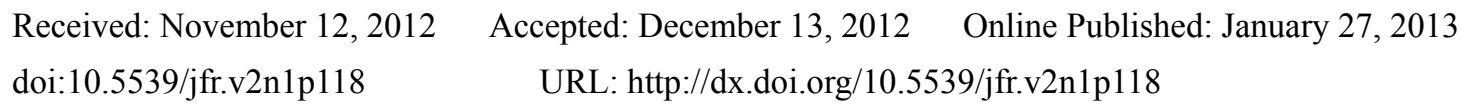

\begin{abstract}
Twin-screw extrusion cooking trials were performed to investigate the differential effects of conventional DDGS (DDGS) and HP-DDG inclusion, as fishmeal replacers, on physical properties (moisture content, water activity, thermal properties, expansion ratio, unit density, bulk density, water absorption, solubility and pellet durability indices, and color) of Rainbow trout (Oncorhynchus mykiss) feed. Four ingredient blends were formulated with 20 and 40\% C- DDGS, and 20 and 40\% HP-DDG, along with other required dietary ingredients. Each diet was extruded using two replications; a fishmeal based diet acted as the control diet. The highest and the lowest extrudate moisture content and water activity were observed for the diets containing 20\% DDGS and 40\% HP-DDG, respectively. Compared to the control diet, increasing HP-DDG content from 20 to $40 \%$ had no effect on the bulk density of the products, while increasing DDGS content from $20-40 \%$ led to a considerable rise in bulk density of the extrudates by 14.2 and $6 \%$, respectively. Also, extrudates with the lowest brightness, greenness, and yellowness values were obtained from the diet containing 20\% DDGS, whereas the most color intensity values were observed for the diets containing 40\% DDGS and 20\% HP-DDG. Increasing DDGS and HP-DDG from $0-40 \%$ caused a remarkable increase in water absorption index, by 72 and $30 \%$, respectively. Likewise, the water solubility index increased, but in a considerably lesser order of magnitude. High pellet durability index of more than $99 \%$ was achieved with inclusion of either DDGS or HP-DDG. None of the diets impacted the thermal properties of the extrudates. Inclusion of 20 and $40 \%$ DDGS resulted in the extrudates with the largest and the smallest unit density values of nearly 887 and $750 \mathrm{~kg} / \mathrm{m}^{3}$, respectively. As was expected, expansion ratio decreased with increasing unit density. Increasing inclusion levels of HP-DDG did not show any effect on unit density or expansion ratio of the products. Future research should concentrate on investigating the effects of both extrusion processing and graded levels of different types of DDGS on Rainbow trout feeds.
\end{abstract}

Keywords: alternative proteins, aquaculture, ethanol co-products, extrudate, trout

\section{Introduction}

Expanding the aquaculture industry enhances the global food security and subsequently helps boost the living standards of the world's growing population; however, the importance of the techno-economic feasibility of aquaculture production must be considered (Pritchard, 1976). Increasing consumer demands for aquaculture products coupled with a limited food supply (i.e. wild fish supply) for feeding the fish have resulted in a remarkable increase in aquafarm production expenses. The largest part of these costs comes for feed in which protein is the most expensive ingredient (Watanabe et al., 2002). The required protein content of the feed varies depending on the species and size of the cultured fish (Craig \& Helfrich, 2002; NRC, 1993), which, in turn, strongly impacts the fish growth performance and thus production efficiency. Fish meal, which is the best source of protein and oil due to its high biological values in terms of essential amino acid, unsaturated fatty acids, minerals, and phospholipids for fish metabolism, comes largely from wild fish stocks (Cheng \& Hardy, 2004). In general, anywhere from 2 to 6 pounds of ocean fish must be used to produce only one pound of farm-raised fish, resulting in a 25\% average transfer efficiency (Marine Aquaculture Task Force, 2007). 
Overexploitation of wild fish stocks to feed the fish not only impacts the ocean ecology balance but increases product costs and reduces the profitability of the aquaculture industry. One way to make the aquaculture industry more environmentally sustainable is to lower the amount of fish meal in fish diets or to stop feeding the fish by fish. Hence, further development of the aquaculture industry as one of the key pillars of sustainable world economic growth requires the substitution alternative protein sources for fish meal.

Since 1950, exploring alternative protein sources to enhance the sustainability of the aquaculture sector has become an area of great interest. Research with the goal of partially or even complete elimination of fish meal in aquafeeds has been conducted to substitute fish meal with other potential sources of protein such as oilseeds, meat byproducts and microbial protein sources (Aas et al., 2006; Coyle et al., 2004; Hardy, 2010; Hardy \& Masumoto, 1990; Jauncey, 2000; Naylor et al., 2005; Rumsey, 1993; Samocha et al., 2004; Shapawi et al., 2007; Storebakken et al., 2004; Webster et al., 1999). It is consensus among the aquaculture scientists that an increased utilization of vegetable-based proteins would help to overcome the issue as they are abundant and economical (Hardy, 2010). Although inclusion of fish meal replacers can reduce the feed cost, complete elimination of fish meal in the aquafeed, particularly for carnivorous species like Trout, has still been questioned, as it may cause severe problems due to the less palatability, digestibility, and lack of essential amino acid profile of the plant-derived proteins (Lim \& Dominy, 1991; Webster et al., 1999). These limiting issues can be influenced by other factors such as the variety of the plant, pretreatment of the plant-based protein before being used in an aquafeed diet formula, and the feed production technology which can affect both biological and physical properties of the feed.

Over the past several years, huge expansion of corn-derived ethanol industry in the U.S. has been accompanied by a remarkable increase in annual production of distillers dried grains (DDGs), a non-fermentable coproduct of ethanol plants. In addition to corn, many other cereal grains such as wheat and barley can be used in ethanol production (Stock et al., 2000; Vander Pol et al., 2005). However, in the Midwest, most ethanol plants use corn as a raw material (Singh et al., 2001). This surge in production of DDGS reinforces the need to achieve a balance between the U.S. supply and consumption markets (Cooper, 2006). The total production of distillers dried grains with solubles (DDGS) from 2007 to 2011 increased by nearly 65\% (AgMRS, 2012). In 2010, the DDGS supply in the US was $33.3 \times 10^{6} \mathrm{Mg}$, with a predicted increase to nearly $39 \times 10^{6} \mathrm{Mg}$ by 2020 (USDA, 2010). DDGS is a valuable source of protein (27-33\%) and fiber (5-12\%) (Rosentrater \& Muthukumarappan, 2006), which has the potential of feeding both the US livestock and economy (Ham et al., 1994; Lim et al., 2009; RFA, 2010; Saunders \& Rosentrater, 2009). On the other hand, comparing with the other plant-based protein such as soy products, DDGS has considerably fewer anti-nutritional factors (ANFs) like trypsin inhibitors (TIA) and lectin (Robinson, 1991; Shiau et al., 1987) and better essential amino acid (EAA) profiles; however, it is still suffering from a lack of some EAAs like lysine, methionine, and tryptophan in comparison to those present in fish meal protein (Cheng \& Hardy, 2004; Chhron \& Mediha, 2008; Metts et al., 2007). Additionally, lower phytate phosphorous content of DDGS lessens the total unavailable phosphorous level of the feed formula and consequently minimizes water pollution as a result of decreased phosphorous excretion into the water of the pond or aquarium. Typically, animal protein source such as fishmeal or poultry by-products and plant protein source such as soy products contain significant amount of phytate phosphorous which is unavailable to most fish (Davis, 1999). Therefore, phytase supplementation of the diet can lead to easier release of phosphorous from phytate, making it more available to fish and reducing the undigested phosphorous discharge (Cain \& Garling, 1995; Cheng \& Hardy, 2002; Papatryphon et al., 1999; Rodehutscord \& Pfeffer, 1995; Storebakken et al., 1998; Sugiura et al., 2001; Vielma et al., 1998, 2000). In addition, better disease resistance of the fish fed was reported with DDGS for some species like catfish (allaboutfeed.net, 2008; Lim et al., 2007).

In general, two conventional methods exist for ethanol production: wet mill processing and dry mill processing. Due to lower initial investments and recent advancements in fermentation technology, dry milling industries have been growing considerably (Belyea et al., 2004; Spiehs et al., 2002). During the dry-milling process, three types of coproducts including distillers dried grains (DDGs), distillers dried solubles (DDS), and distillers dried grains with solubles (DDGS) are produced after the starch fermentation and distillation of fermented mash. The soluble portion of the residual coproduct is evaporated and condensed distillers solubles (CDS) are produced. The solid portion of the remaining fermentation residue and condensed distillers solubles are both subjected to drying and produce either distillers dried grains (DDG) or distillers dried solubles (DDS) (Singh et al., 2005; University of Minnesota, 2008). When these two coproducts are mixed and dried, distillers dried grains with solubles (DDGS) is produced. DDS is a viable source of vitamin and fat and contains the highest nutrient concentration compared to those of DDGS and DDG (University of Minnesota, 2008). Furthermore, the nutrient amounts in DDGS are almost triple those of raw corn (Jacques et al., 2003) as a result of the fermentation and 
yeast metabolism. Recently biorefinery plants have employed a new technique to increase the ethanol production yield. In the new dry-milling process, whole corn is fractionated into several fractions including germ, bran, and endosperm. Germ fraction contains high fat and phosphorous concentrations in addition to a better essential amino acids profile. Endosperm fraction is subjected to fermentation and ethanol recovery. Indeed, pre-removal of the nonfermentable fraction of corn is the main reason for the ethanol yield increase (Singh et al., 2005). The coproduct of this process is DDG, which is high in protein but low in fat. Typically, conventional DDGS (DDGS) contains approximately 30\% protein (Rosentrater \& Muthukumarappan, 2006; Spiehs et al., 2002). The protein content of DDG is almost 1.5 times that of DDGS; hence, it is called HP-DDG (Robinson et al., 2008). Moreover, using HP-DDG provides higher available phosphorous content thus reducing the need for phosphorous supplementation and subsequently the phosphorous excreted into the water. Robinson et al. (2008) believed that HP-DDG nutritional values are much more consistent than those of DDGS. However, the grain variety and production processing parameters such as over processing during drying can affect the variability and consistency of the nutrient characteristics of the corn ethanol coproducts (Abo-State et al., 2009; Belyea et al., 1998, 2004).

The valuable nutrient compositions of corn ethanol coproducts have motivated researchers to explore the potential incorporation of distillers grains in aquadiet formulations. Many researchers have studied how using DDGS in aquafeed affects the growth performances and biological responses of species such as Nile tilapia, Channel catfish, Yellow perch, and Troutas well as the produced feed physical properties and applied operational conditions for producing the feed. For example, Wu et al. (1994) investigated the effects of three DDGS-based diets containing $36 \%$ protein without fish meal as well as $32 \%$ protein with and without fishmeal on the growth rate of Nile tilapia, but did not observe any significant difference among the three diets. In a later study, they achieved the highest weight gain and protein efficiency ratio with diets containing $40 \%$ protein- $35 \%$ DDGS and $40 \%$ protein- $49 \%$ DDGS for Tilapia fry, respectively (Wu et al., 1996). In a later study, Schaeffer et al. (2009) suggested that diets with $20 \%$ DDGS inclusion can result in a similar biological response to that of the commercial diets for Nile tilapia. Yet another study evaluated the growth response of channel catfish fed a diet containing 30\% DDGS, and no ill effect was observed (Tidwell et al., 1990). Fish meal replacement with 70\% DDGS and 4\% lysine supplementation in channel catfish diet was studied and relatively similar results were observed (Lim et al., 2009; Webster, 1991; Zhou et al., 2010). Robinson and Li (2008) studied the effect of replacing fish meal with several plant-based protein for channel catfish and suggested that at least $30 \%$ DDGS can be used in the diet when lysine is supplemented. More recently Schaeffer et al. (2011) conducted several feeding trials to explore the growth characteristics (i.e. growth rate, gain weight, feed conversion, and digestibility) of yellow perch fed with diets containing varying amounts of soybean meal and DDGS. They reported that blends with less than 50\% DDGS inclusion produced the highest growth performance, but increasing the DDGS portion to $75 \%$ lead to a significant decrease in growth response for yellow perch. This study also suggested that a combination of DDGS and SBM can be included in yellow perch diet up to $49.5 \%$ with no negative effect. Initial research on the potential inclusion of corn ethanol coproducts (DDGS and DDS) in trout diets was conducted by Philips et al. in 1949 and 1964, respectively. Fowler and Banks (1976) and Hughes (1987) explored the growth characteristics of Rainbow trout fed diets containing corn ethanol coproducts obtained from different production stages. Cheng et al. (2003) explored the effect of combined soybean meal and DDGS inclusion with and without EAAs (methionine) supplementation on trout performance and reported that up to $50 \%$ of fishmeal can be successfully replaced by this combination of alternative protein sources while the diet is supplemented with methionine. Later on, Cheng and Hardy (2004) performed a feeding trial to investigate the effect of $7.5 \%, 15 \%$, and $22.5 \%$ DDGS-included diets with and without EAA supplementation, mainly lysine and methionine, on the performance of Rainbow trout. The study suggested that inclusion of $15 \%$ DDGS without using EAA supplemental and 22.5\% DDGS with EAA supplementation may be suitable for trout. Furthermore, in 2008 the USGC reported typical DDGS incorporation rates obtained for various species. Robinson et al. (2009) examined the effect of various corn-based distillers grains on the biological responses (i.e. growth, feed efficiency, and body composition) of channel catfish. When $20 \%$ HP-DDG was used, they did not observe any significant difference in growth characteristics compared to those on the control diet. Very few studies have explored the effect of HP-DDG inclusion on fish growth characteristics for Rainbow trout. Recently, Barnes et al. (2012) conducted a feeding trial for Rainbow trout fed with HP-DDG included feed and examined the effect of HP-DDG along with EAA and phytase supplementations on trout growth and feed conversion. They suggested that up to $20 \%$ HP-DDG with amino acid supplementation can be successfully incorporated into trout diets.

As mentioned before, although a well pre-balanced nutritious aquadiet is important to achieve an optimal growth performance, suitable production techniques and well-controlled operational conditions play crucial roles in 
producing quality aquafeeds (Gokulakrishnana \& Bandyopadhyay, 1995). Though not the only manufacturing method, extrusion processing is the most common and economic technology used in the aqua-feed industry. It can improve production productivity and versatility (Kiang, 1998) and can be used for production of floating, sinking and slow sinking aquaculture feed (Opstvedt et al., 2003). An extruder is a bioreactor made of three main parts (i.e. screw, jacketed barrel, and die) in which several unit operations are combined to simultaneously pump, mix, convey, work the raw feed ingredient into a cooked dough, and eventually shape the extruded products through a restricted die using thermal and mechanical energy. The machine's short processing time helps to retain nutrients in cooked extruded products. This cooking process can also help to detoxify the ingredient blend, inactivate the antinutritional factors and undesired enzymes (Cheftel, 1986; Romarheim et al., 2005), and improve the digestibility, and palatability of the product (Cheftel, 1986; Tran et al., 2008). However, it also may have some detrimental effects in terms of the product's nutritional quality including reduction of protein quality and un-bioavailability of some EAAs due to Maillard reaction and loss of heat-labile vitamins due to exposing to high temperature (Tran et al., 2008). An extruder's performance is greatly influenced by variables such as feed composition, moisture content, barrel temperature, screw speed, mass flow rate, and residence time in the extruder as well as the physics behind the barrel, screw and dies (i.e. configuration and size). As the screw rotates, mixes, and conveys the feed mixture along the barrel, heat is provided either by steam and/or water injection or via an electrical heater in addition to that derived from friction. The interaction of high shear and temperature developing inside the extruder with the present water leads to a complex physiochemical and nutritional alterations in the extruding dough and final products particularly due to gelatinization of starch and denaturation of protein components of the feed blend (Guy, 2001). Hence, applying an appropriately formulated diet composition (Cavalcanti \& Behnke, 2005a, 2005b; Faubion et al., 1982; Mathew et al., 1999a, 1999b) along with optimal process conditions (Banerjee \& Chakraborty, 1998; Lin et al., 1998; Mathew et al., 1999c; Rolfe et al., 2000) are vitally important in producing physically available and nutritionally viable extruded fish feed (Gokulakrishnana \& Bandyopadhyay, 1995; Wood, 1995). Furthermore, both physical and nutritional properties of the extruded aquafeed can vary depending upon the fish species. In terms of the physical properties, water stability, expansion ratio, and durability index of the extruded feed are very important (Chevanan et al., 2009; Rolfe et al., 2001; Wood, 1995). Generally, the more water stable the extruded feed, the longer the availability of the feed for fish. Since the higher water stability can prevent rapid disintegration of the feed and consequent loss of nutrients when placing it in water. Additionally, the more expanded extrudates exhibit better digestibility due to increased starch gelatinization during the process (Ali, 1998; Case et al., 1992; Gokulakrishnana \& Bandyopadhyay, 1995; Rout, 1997; Thomas et al., 1999). Also, the more expanded extrudates float longer which is somehow the main goal in fish feed processing (Vens-Cappell, 1984), though it is not a determining factor as the different cultured ration can be trained to obtain either the floating or sinking food from different depths of the water. On the other hand, the higher the durability index, the more resistant the extrudate against mechanical forces during the storage and transportation (Chevanan et al., 2009; Colonna et al., 1989; Rolfe et al. 2001). In other words, the ultimate quality of the extruded fish feed is a function of feed blend chemical composition and extrusion processing parameters (Ibanoglu et al., 1996; Thomas et al., 1999). In addition, selecting the proper extruder configuration based on the feed ingredients and final properties of the product are key factors in achieving an optimal extrusion process (Tran et al., 2008).

The effects of extrusion processing on the physical properties of DDGS-based aquafeeds have been well documented. Chevanan et al. (2007a) examined the effect of raw blend moisture content, die dimension, and extruder temperature on Nile tilapia diets formulated with $40 \%$ DDGS inclusions using a single-screw extruder. They observed that an appropriate combination of blend moisture content, extruder temperature, and die geometry was essential for production of good quality DDGS-based Nile tilapia feed. In another study conducted by this research group, they investigated the effect of graded levels of DDGS inclusion on extruded Nile tilapia diets produced by a twin-screw extruder and suggested that up to 60\% DDGS can be included for production of floating feed (Chevanan et al., 2007b). In a later study, Chevanan et al. (2008) explored the effect of DDGS, moisture content, and screw speed on the physical properties of extrudates in single-screw extrusion. They reported that almost all of the tested physical properties of the final product (such durability, specific gravity, porosity, and color) were significantly influenced by these variables. In a follow-up s study, they improved the DDGS- based extrudate quality using the binding properties of whey protein (Chevanan et al., 2009). Later on, they studied the processing behavior of the DDGS-based blends for Nile tilapia and proposed best-fit response surface models for extrusion processing properties including mass flow rate, net torque required, specific mechanical energy consumption, and apparent viscosity (Chevanan et al., 2010). In an attempt to optimize the extrusion processing condition for DDGS-based Nile tilapia diet, Rosentrater and Tulbek (2010) and Fallahi et al. (2011) carried out research to evaluate the effects of conditioner steam, extruder water and screw speed on the 
final properties of DDGS-based Nile tilapia diets in a pilot-scale twin-screw extruder. Ayadi et al. (2011a, 2011b) conducted two extrusion studies to investigate the extrusion processing effects on DDGS-based yellow perch diets. Using a laboratory scale single-screw extruder at a barrel temperature profile of $40-90-100^{\circ} \mathrm{C}$ (Feeding zone: $40^{\circ} \mathrm{C}$; conditioning zone: $90^{\circ} \mathrm{C}$; metering zone: $100^{\circ} \mathrm{C}$ ) and a constant screw speed of $230 \mathrm{rpm}$, they could produce viable extruded diets for yellow perch with 50\% DDGS inclusion (Ayadi et al., 2011a). In a subsequent study using a twin-screw extruder, they achieved higher expansion ratio and compression strength for the extrudates containing $40 \%$ DDGS compared to those of the extrudates produced in their first study (Ayadi et al., 2011b). They also performed another twin-screw extrusion study to produce a DDGS-based diet for Rainbow trout at graded levels of DDGS and concluded that DDGS could be a suitable fish meal replacer in the Rainbow trout diet (Ayadi et al., 2011c).

To our knowledge, no literature result concerning the effects of extrusion cooking process on Rainbow trout diets containing HP-DDG is available. Therefore, the goals of our study are 1) to produce feed for Rainbow trout (Oncorhynchus mykiss) using both C- DDGS and HP-DDG as the alternative protein sources and 2) to investigate the physical properties of corn ethanol coproducts protein-based extrudates produced by twin-screw extrusion.

\section{Materials and Methods}

\subsection{Experimental Design and Feed Blend Preparation}

Four isocaloric ( $3.06 \mathrm{kcal} / \mathrm{g})$ experimental diets were formulated with two levels of DDGS (20 and $40 \% \mathrm{db})$ and two levels of HP-DDG ( 20 and $40 \% \mathrm{db}$ ), in combination with calculated amounts of the other required dietary ingredients including corn gluten meal, wheat flour, vitamin mix, minerals, and essential amino acids, to contain a net protein content of $\sim 40 \% \mathrm{db}$. Table 1 lists the percent ingredient composition (dry basis percent) for the experimental diets for rainbow trout and the control feed. A fishmeal based diet $(100 \%$ fishmeal as the protein source) was used as the control feed. DDGS and HP-DDG were provided by Dakota Ethanol (Wentworth, SD), and were ground to a fine particle size of approximately $100 \mu \mathrm{m}$ with a laboratory-scale grinder (Model S500 disc mill, Gen Mills, Clifton, NJ). Corn gluten meal from Consumers Supply Distributing Company (Sioux City, IA); wheat flour from Bob's Red Mill Natural Foods, Inc. (Milwaukie, OR); CMC from USB Corporation (Cleveland, OH); vitamin premix and minerals were from Lortscher Agri Service, Inc. (Bern, KS). The ingredients were mixed with a laboratory-scale mixer (Model 600, Hobart Corporation, Troy, OH) for 3 min; then, the vitamin premix was added to the rest of the ingredients, and the blend was mixed with a twin shell dry blender (The Patterson-Kelly Co. Inc., East Stroudsburg, PA) at $60 \mathrm{rpm}$ for $10 \mathrm{~min}$ to produce homogenous blends. The resulting blends were then stored at ambient temperature overnight. 
Table 1. Ingredient components ( $\mathrm{g} / 100 \mathrm{~g})$ of the fees blend

\begin{tabular}{|c|c|c|c|c|c|}
\hline Components (\%db) & Control & Diet 1 & Diet 2 & Diet 3 & Diet 4 \\
\hline \multicolumn{6}{|c|}{ Dry weight of ingredients (g/100g) } \\
\hline HP-DDG ${ }^{\mathrm{a}}$ & 0.00 & 0.00 & 0.00 & 11.08 & 22.21 \\
\hline DDGS $^{\mathrm{b}}$ & 0.00 & 11.00 & 20.94 & 0.00 & 0.00 \\
\hline Fish meal $^{c}$ & 45.90 & 45.00 & 33.71 & 45.57 & 34.10 \\
\hline Corn gluten meal $^{\mathrm{d}}$ & 28.07 & 24.30 & 24.19 & 22.30 & 22.25 \\
\hline Whole wheat flour ${ }^{\mathrm{e}}$ & 22.47 & 14.45 & 12.10 & 12.27 & 12.25 \\
\hline $\mathrm{CMC}^{\mathrm{f}}$ & 0.76 & 0.57 & 0.84 & 0.46 & 0.88 \\
\hline Vitamin premix ${ }^{\mathrm{g}}$ & 0.63 & 0.62 & 0.62 & 0.62 & 0.62 \\
\hline Mineral mix ${ }^{\mathrm{h}}$ & 0.00 & 0.12 & 0.12 & 0.12 & 0.12 \\
\hline Oils & $3 / 4$ & $3 / 4$ & $3 / 4$ & $3 / 4$ & $3 / 4$ \\
\hline Supplementsi (total from below) & 2.17 & 3.94 & 7.47 & 7.58 & 7.56 \\
\hline Stay-C & 0.63 & 0.62 & 0.62 & 0.62 & 0.62 \\
\hline Choline & 0.00 & 0.00 & 0.00 & 0.00 & 0.00 \\
\hline Phytase & 0.00 & 0.05 & 0.05 & 0.05 & 0.05 \\
\hline DVAqua & 0.16 & 0.16 & 0.15 & 0.16 & 0.16 \\
\hline Arginine & 0.00 & 0.00 & 0.00 & 0.00 & 0.00 \\
\hline Lysine & 0.00 & 0.62 & 0.62 & 0.62 & 0.62 \\
\hline Isoleucine & 0.00 & 0.37 & 0.37 & 0.37 & 0.37 \\
\hline Histidine & 0.00 & 0.12 & 0.12 & 0.12 & 0.12 \\
\hline Glycine & 0.00 & 0.00 & 0.00 & 0.00 & 0.00 \\
\hline Methionine & 0.00 & 0.62 & 0.62 & 0.62 & 0.62 \\
\hline Taurine & 0.00 & 0.00 & 0.00 & 0.00 & 0.00 \\
\hline Sodium chloride & 0.63 & 0.62 & 1.11 & 1.12 & 1.12 \\
\hline Potassium chloride & 0.76 & 0.75 & 0.86 & 0.87 & 0.87 \\
\hline Mgnesium oxide & 0.00 & 0.00 & 0.12 & 0.12 & 0.12 \\
\hline Calcium phosphate & 0.00 & 0.00 & 2.84 & 2.87 & 2.87 \\
\hline Total & 100.00 & 100.01 & 100.00 & 100.00 & 100.00 \\
\hline \multicolumn{6}{|c|}{${ }^{\mathrm{a}}$ HP-DDG, Dakota Ethanol (Wentworth, SD) } \\
\hline \multicolumn{6}{|c|}{${ }^{\mathrm{b}}$ DDGS, Dakota Ethanol (Wentworth, SD) } \\
\hline \multicolumn{6}{|c|}{${ }^{\mathrm{c}}$ Menhaden fish meal, Omega Protein Inc (Houston, TX). } \\
\hline \multicolumn{6}{|c|}{${ }^{\mathrm{d}}$ Corn gluten meal, Consumers Supply Distributing Company (Sioux City, IA) } \\
\hline \multicolumn{6}{|c|}{ e Whole wheat flour, Bob's Red Mill Natural Foods, Inc. (Milwaukie, OR) } \\
\hline \multicolumn{6}{|c|}{${ }^{f}$ Carboxyl methyl cellulose (CMC), USB Corporation (Cleveland, OH) } \\
\hline \multicolumn{6}{|c|}{${ }^{9}$ Vitamin premix, Lortscher Agri Service, Inc. (Bern, KS) } \\
\hline${ }^{\mathrm{h}}$ Mineral, Lortscher Agri Service, Ir & $\mathrm{rn}, \mathrm{KS})$ & & & & \\
\hline
\end{tabular}

\subsection{Extrusion Processing}

The experimental extrusion cooking process was performed using a semi industrial, co-rotating, self-wiping, and fully intermeshing twin-screw extruder (Wenger TX-52, Sabetha, KS) which had a $30 \mathrm{hp}$ motor and throughput of $50-250 \mathrm{~kg} / \mathrm{h}$. Using a dry feed hopper, the ingredient blends were transferred and conveyed into a continuous preconditioner where the ingredients were mixed and the desired moisture content and temperature were adjusted via steam injection at a rate of $0.11-0.16 \mathrm{~kg} / \mathrm{min}$. Then, the blends were transferred into the extruder at a feeder rate of $20 \mathrm{~kg} / \mathrm{h}$. The screws' diameter and L/D ratio of the extruder barrel were $52 \mathrm{~mm}$ and 25.5:1, respectively. The screws used in this experiment had 25 individual sections, and the configuration from the feeding to the die section, was composed of: four conveying screws, three shear locks, one conveying screw, one conveying screw backward, three conveying screws, one conveying screw backwards, four conveying screws, one shear lock, one interrupted flight conveying screw, one conveying screw, one interrupted flight conveying screw, one conveying screw, one interrupted flight conveying screw, one shear lock, and finally a screw with a cone-shaped end point. Moreover, the barrel was composed of eight temperature zones which were set at 25 to $90^{\circ} \mathrm{C}$. The temperature profile of the barrel varied, depending on the actual temperature of each zone and the 
extrudates' properties. The amount of water added to the extruder was maintained at 0.11 to $0.19 \mathrm{~kg} / \mathrm{min}$. It had two die nozzles each of which with circular opening of $3 \mathrm{~mm}$. After exiting the die section, the extrudates were cut into desired lengths, using a three blade cutter.

\subsection{Measurement of Extrusion Processing Parameters}

\subsubsection{Temperature (T)}

Temperatures of the raw blends inside the hopper, at the conditioner exit and die zone were all monitored by a portable infrared thermometer (Model 42540, Extech Instruments Corporation, Waltham, MA).

\subsection{Measurement of Extrudate Physical Properties}

The extruded diets were cooled for $72 \mathrm{~h}$ at ambient temperature $\left(24 \pm 1^{\circ} \mathrm{C}\right)$ and dried in an oven (Model TAH-500, Grieve Corporation, Round Lake, IL) for $24 \mathrm{~h}$ at $45^{\circ} \mathrm{C}$. Then, the dried extrudates were subjected to extensive physical property analyses, including moisture content $(\mathrm{MC})$, water activity $\left(\mathrm{a}_{\mathrm{w}}\right)$, thermal conductivity $(\mathrm{K})$, thermal resistivity (R), thermal diffusivity $(\alpha)$, expansion ratio (ER), unit density (UD), bulk density (BD), water absorption and water solubility indices (WAI, WSI), pellet durability index (PDI), and color.

\subsubsection{Moisture Content (MC)}

MC of the extrudates was determined according to AACC method 44-19 (2000), using a laboratory-scale oven (Fischer Scientific) at $135^{\circ} \mathrm{C}$ for $2 \mathrm{~h}$.

\subsubsection{Water Activity $\left(\mathrm{a}_{\mathrm{w}}\right)$}

Water activity of the extrudates was measured with a water activity meter ( $a_{w}$ Sprint TH-500, Novasina, Pfäffikon, Switzerland). The system was calibrated according to the procedure specified by the manufacturer.

\subsubsection{Thermal Properties}

Thermal conductivity $(\mathrm{k})$, thermal diffusivity $(\alpha)$, and thermal resistivity $(\mathrm{R})$ were determined using a thermal properties analyzer (KD2, Decagon Devices, Inc., Pullman, WA).

\subsubsection{Expansion Ratio (ER)}

The diametral expansion of the extrudates was determined as the ratio of extrudate diameter $(\mathrm{mm})$ to the diameter (mm) of the die nozzle, using a digital caliper (Digimatic Series No. 293, Mitutoyo Co., Tokyo, Japan.), following Conway and Anderson (1973) and van Zuilichem etal. (1975).

\subsubsection{Unit Density (UD)}

Assuming cylindrical shapes for the extrudates, UD was determined as the ratio of the mass $(\mathrm{g})$ to volume $\left(\mathrm{cm}^{3}\right)$ for ten randomly chosen extrudates, following Jamin and Flores (1998) and Rosentrater et al. (2005). The mass of each of the extrudates was measured with an analytical balance (Adventurer. AR 1140, Ohaus Corp. Pine Brook, NJ) and the diameter of each was measured with a digital caliper (Digimatic Series No. 293, Mitutoyo Co., Tokyo, Japan).

\subsubsection{Bulk Density (BD)}

Using a standard bushel tester (Seedburo Equipment Company, Chicago, IL), BD $\left(\mathrm{g} / \mathrm{cm}^{3}\right)$ was measured as the ratio of the mass of the extrudates (g) occupying a given bulk volume, to the volume of the bulk $(0.5 \mathrm{~L})$ (USDA, 1999).

\subsubsection{Water Absorption and Water Solubility Indices (WAI, WSI)}

Using a laboratory-scale grinder (Chemical Rubber Co, CRC, Germany) extrudate samples were ground to a particle size of approximately $150 \mu \mathrm{m}$, then $2.5 \mathrm{~g}$ of the finely ground sample were placed in a $50 \mathrm{~mL}$ centrifuge tube, and $30 \mathrm{~mL}$ distilled water at $30^{\circ} \mathrm{C}$ was added to the tube. After intermittently stirring for $30 \mathrm{~min}$, the suspension was centrifuged at $3000 \mathrm{Xg}$ for $15 \mathrm{~min}$ using a laboratory-scale centrifuge (accuSpinTM 400, Thermo Electron Corporation). Thereafter, the supernatant phase was transferred into aluminum dishes and placed in a laboratory oven (Fisher Scientific) at $135^{\circ} \mathrm{C}$ for $2 \mathrm{~h}$. WAI was calculated as the mass ratio of the remaining gel in the centrifuge tube to the original mass of the sample, equation (1):

$$
\text { WAI }(-)=[\text { Mass of gel }] /[\text { Mass of sample }]
$$

where masses were determined in $\mathrm{g}$.

Subsequently, WSI (\%) was calculated as the mass ratio of the extracted dry solid to the original sample mass, following Anderson et al. (1969) and Jones et al. (2000). 


\subsubsection{Pellet Durability Index (PDI)}

PDI was determined following ASAE standard method S269.4 (ASAE, 1996); $200 \mathrm{~g}$ of the extruded sample was tumbled inside a PDI tester (model PDT -110, Seedburo Equipment Co., Chicago, IL) for $10 \mathrm{~min}$, and then sieved manually via a No. 6 screen. PDI was calculated with equation (2), where $M_{a}$ and $M_{b}$ are the mass (g) of the extrudates after tumbling and before tumbling, respectively:

$$
\operatorname{PDI}(\%)=[M a] /[M b] \times 100
$$

2.4.9 ColorDetermination ( $\mathrm{L}^{*}, \mathrm{a}^{*}$, and $\mathrm{b}^{*}$ )

Brightness/darkness $\left(\mathrm{L}^{*}\right)$, redness/greenness $\left(\mathrm{a}^{*}\right)$, and yellowness/blueness $\left(\mathrm{b}^{*}\right)$ were measured using a spectrophotometer (Lab Scan XE, Hunter Lab, Reston, VA).

\section{Statistical Analysis}

All measurements were made in triplicate, except for UD and ER, where ten measurements were taken. All collected data were analyzed with Microsoft Excel v.2010 and SAS v.9.0 software (SAS Institute, Cary, NC) using a Type I error rate $(\alpha)$ of 0.05 , by analysis of variance (ANOVA) to find if there were significant differences among control diet and experimental diets. Then post-hoc LSD tests were used to determine where the specific differences occurred $(\mathrm{p}<0.05)$.

Table 2. Proximate compositions of the diets $(5 \mathrm{db})$

\begin{tabular}{lccccc}
\hline & \multicolumn{5}{c}{ Diet } \\
\cline { 2 - 6 } Composition (\%db) & Control & Diet 1 & Diet 2 & Diet 3 & Diet 4 \\
\hline Crude Protein & 39.96 & 41.89 & 38.05 & 42.03 & 39.79 \\
Crude Fat & 16 & 16.25 & 16.28 & 16.18 & 16.24 \\
Crude Fiber & 0.36 & 0.36 & 0.36 & 0.36 & 0.36 \\
Ash & 2.03 & 2.03 & 2.63 & 2.63 & 2.63 \\
\hline
\end{tabular}

\section{Results and Discussion}

\subsection{Extrusion Processing Parameters}

\subsubsection{Dough Temperature during Extrusion Processing ( $\mathrm{T}$ )}

Temperatures at three points of the process were monitored. As shown in Table 3, substitution of DDGS and HP-DDG significantly influenced the measured processing temperatures. Inclusion of $20 \%$ DDGS and $20 \%$ HP-DDG led to a $3.1 \%$ and $7.2 \%$ increase in processing temperature at conditioner section $\left(\mathrm{T}_{\mathrm{C}}\right)$, respectively. Further addition of DDGS and HP-DDG up to $40 \%$, resulted in $4.6 \%$ and $5 \%$ increase in $\mathrm{T}_{\mathrm{C}}$, respectively. While this increase caused a $5.2 \%$ and $2.5 \%$ increase in $\mathrm{T}_{\mathrm{d}}$ compared to that of the control diet. Increasing DDGS and HP-DDG from $20 \%$ to $40 \%$, no considerable changes were observed for $\mathrm{T}_{\mathrm{C}}$ and $\mathrm{T}_{\mathrm{d}}$ of the extrudates. Temperature variation inside the barrel can affect the performance of extrusion process as well as the final extrudates qualities. Proportional increasing rate of temperature along the extruder length can be ascribed to both heat addition as well as frictional heating. Also, the temperature development inside the barrel can vary depending upon the thermal properties of the dough (i.e. thermal conductivity and thermal diffusivity), degree of mixing, and velocity of dough flow (Chevanan et al., 2007a).

\subsection{Measurement of Extrudate Physical Qualities}

All the measured physical properties of the final products including moisture content, water activity, thermal properties, expansion ratio, unit density, bulk density, water absorption and water solubility indices, pellet durability index, and color are provided in Table 4. 
Table 3. Treatment effects on extrusion processing parameters

\begin{tabular}{lccccc}
\hline & \multicolumn{5}{c}{ Treatment } \\
\cline { 2 - 6 } Parameter & Control & Diet1 & Diet 2 & Diet 3 & Diet 4 \\
\hline Processing temperature $\left({ }^{\circ} \mathrm{C}\right)$ & & & & & \\
Feeder zone & $25.44^{\mathrm{c}}$ & $26.32^{\mathrm{b}}$ & $26.72^{\mathrm{a}}$ & $26.75^{\mathrm{a}}$ & $26.33^{\mathrm{b}}$ \\
& $(0.20)$ & $(0.29)$ & $(0.05)$ & $(0.18)$ & $(0.46)$ \\
Conditioner zone & $30.76^{\mathrm{b}}$ & $31.72^{\mathrm{a}}$ & $32.18^{\mathrm{a}}$ & $32.96^{\mathrm{a}}$ & $32.34^{\mathrm{a}}$ \\
& $(0.53)$ & $(0.74)$ & $(0.83)$ & $(0.65)$ & $(1.13)$ \\
Die zone & $46.02^{\mathrm{b}}$ & $47.66^{\mathrm{a}}$ & $48.40^{\mathrm{a}}$ & $48.28^{\mathrm{a}}$ & $47.18^{\mathrm{a}}$ \\
& $(1.03)$ & $(0.43)$ & $(0.25)$ & $(0.28)$ & $(1.01)$ \\
\hline
\end{tabular}

Mean values among treatments followed by similar letters for a given dependent variable are not significantly different at $\mathrm{P}<0.05$. Values in parentheses are standard deviation.

Table 4. Main effects on extrudate physical properties

\begin{tabular}{|c|c|c|c|c|c|}
\hline \multirow[t]{2}{*}{ Property } & \multicolumn{5}{|c|}{ Treatment } \\
\hline & Control & Diet1 & Diet2 & Diet 3 & Diet 4 \\
\hline MC (\%) & $\begin{array}{l}8.32^{\mathrm{a}} \\
(0.12)\end{array}$ & $\begin{array}{l}7.74^{b} \\
(0.49)\end{array}$ & $\begin{array}{l}5.76^{\mathrm{c}} \\
(0.34)\end{array}$ & $\begin{array}{l}5.30^{\mathrm{c}} \\
(0.79)\end{array}$ & $\begin{array}{l}4.60^{\mathrm{d}} \\
(0.32)\end{array}$ \\
\hline $\mathrm{a}_{\mathrm{w}}(-)$ & $\begin{array}{l}0.48^{\mathrm{a}} \\
(0.01)\end{array}$ & $\begin{array}{l}0.43^{\mathrm{b}} \\
(0.01)\end{array}$ & $\begin{array}{l}0.24^{\mathrm{c}} \\
(0.01)\end{array}$ & $\begin{array}{l}0.23^{\mathrm{d}} \\
(0.01)\end{array}$ & $\begin{array}{l}0.21^{\mathrm{e}} \\
(0.02)\end{array}$ \\
\hline $\mathrm{k}(\mathrm{W} / \mathrm{m} \cdot \mathrm{C})$ & $\begin{array}{l}0.056^{\mathrm{a}} \\
(0.01)\end{array}$ & $\begin{array}{l}0.056^{\mathrm{a}} \\
(0.01)\end{array}$ & $\begin{array}{l}0.056^{\mathrm{a}} \\
(0.01)\end{array}$ & $\begin{array}{l}0.052^{\mathrm{a}} \\
(0.00)\end{array}$ & $\begin{array}{c}0.055^{\mathrm{a}} \\
(0.00)\end{array}$ \\
\hline $\mathrm{R}(\mathrm{m} \cdot \mathrm{C} / \mathrm{W})$ & $\begin{array}{c}18.47^{\mathrm{ab}} \\
(0.89)\end{array}$ & $\begin{array}{l}17.50^{\mathrm{b}} \\
(0.85)\end{array}$ & $\begin{array}{l}17.80^{\mathrm{b}} \\
(0.39)\end{array}$ & $\begin{array}{l}19.11^{\mathrm{a}} \\
(1.14)\end{array}$ & $\begin{array}{c}18.42^{\mathrm{ab}} \\
(0.66)\end{array}$ \\
\hline$\alpha\left(\mathrm{mm}^{2} / \mathrm{s}\right)$ & $\begin{array}{l}0.16^{\mathrm{ab}} \\
(0.01)\end{array}$ & $\begin{array}{l}0.15^{\mathrm{c}} \\
(0.01)\end{array}$ & $\begin{array}{c}0.16^{\mathrm{b}} \\
(0.00)\end{array}$ & $\begin{array}{l}0.17^{\mathrm{a}} \\
(0.01)\end{array}$ & $\begin{array}{l}0.16^{\mathrm{ab}} \\
(0.01)\end{array}$ \\
\hline ER (-) & $\begin{array}{l}1.18^{\mathrm{a}} \\
(0.08)\end{array}$ & $\begin{array}{l}1.043^{\mathrm{c}} \\
(0.05)\end{array}$ & $\begin{array}{l}1.13^{\mathrm{b}} \\
(0.02)\end{array}$ & $\begin{array}{l}1.16^{\mathrm{ab}} \\
(0.07)\end{array}$ & $\begin{array}{l}1.16^{\mathrm{ab}} \\
(0.04)\end{array}$ \\
\hline $\mathrm{UD}\left(\mathrm{kg} / \mathrm{m}^{3}\right)$ & $\begin{array}{c}731.70^{\mathrm{b}} \\
(100.11)\end{array}$ & $\begin{array}{l}886.65^{\mathrm{a}} \\
(89.82)\end{array}$ & $\begin{array}{l}749.58^{\mathrm{b}} \\
(36.62)\end{array}$ & $\begin{array}{l}755.72^{b} \\
(90.45)\end{array}$ & $\begin{array}{c}750.92^{\mathrm{b}} \\
(75.35)\end{array}$ \\
\hline $\mathrm{BD}\left(\mathrm{kg} / \mathrm{m}^{3}\right)$ & $\begin{array}{c}572.15^{\mathrm{c}} \\
(1.29)\end{array}$ & $\begin{array}{c}666.91^{\mathrm{a}} \\
(2.05)\end{array}$ & $\begin{array}{c}601.13^{\mathrm{b}} \\
(0.29)\end{array}$ & $\begin{array}{c}575.89^{\mathrm{c}} \\
(5.89)\end{array}$ & $\begin{array}{l}583.98^{\mathrm{c}} \\
(22.78)\end{array}$ \\
\hline WAI (-) & $\begin{array}{l}3.48^{\mathrm{c}} \\
(0.06)\end{array}$ & $\begin{array}{l}3.87^{\mathrm{b}} \\
(0.10)\end{array}$ & $\begin{array}{l}4.21^{\mathrm{a}} \\
(0.18)\end{array}$ & $\begin{array}{l}2.45^{\mathrm{d}} \\
(0.10)\end{array}$ & $\begin{array}{l}2.58^{\mathrm{d}} \\
(0.27)\end{array}$ \\
\hline WSI (\%) & $\begin{array}{l}14.81^{\mathrm{b}} \\
(0.24)\end{array}$ & $\begin{array}{c}15.17^{\mathrm{ab}} \\
(0.39)\end{array}$ & $\begin{array}{c}15.05^{\mathrm{ab}} \\
(0.52)\end{array}$ & $\begin{array}{l}16.70^{\mathrm{a}} \\
(2.74)\end{array}$ & $\begin{array}{c}16.16^{\mathrm{ab}} \\
(1.80)\end{array}$ \\
\hline PDI (\%) & $\begin{array}{c}99.42^{\mathrm{ab}} \\
(0.05)\end{array}$ & $\begin{array}{c}99.33^{\mathrm{b}} \\
(0.45)\end{array}$ & $\begin{array}{c}99.54^{\mathrm{ab}} \\
(0.03)\end{array}$ & $\begin{array}{c}99.59^{\mathrm{a}} \\
(0.18)\end{array}$ & $\begin{array}{c}99.64^{\mathrm{a}} \\
(0.07)\end{array}$ \\
\hline $\mathrm{L}^{*}(-)$ & $\begin{array}{l}22.36^{\mathrm{c}} \\
(0.21)\end{array}$ & $\begin{array}{l}20.66^{d} \\
(0.20)\end{array}$ & $\begin{array}{c}22.99^{\mathrm{ab}} \\
(0.14)\end{array}$ & $\begin{array}{l}23.14^{\mathrm{a}} \\
(0.44)\end{array}$ & $\begin{array}{l}22.78^{b} \\
(0.39)\end{array}$ \\
\hline$a^{*}(-)$ & $\begin{array}{l}5.50^{\mathrm{a}} \\
(0.10)\end{array}$ & $\begin{array}{l}4.83^{\mathrm{c}} \\
(0.10)\end{array}$ & $\begin{array}{l}5.50^{\mathrm{a}} \\
(0.09)\end{array}$ & $\begin{array}{l}5.25^{\mathrm{b}} \\
(0.12)\end{array}$ & $\begin{array}{l}5.10^{\mathrm{b}} \\
(0.32)\end{array}$ \\
\hline$b^{*}(-)$ & $\begin{array}{l}8.99^{\mathrm{c}} \\
(0.21)\end{array}$ & $\begin{array}{l}7.83^{\mathrm{d}} \\
(0.09)\end{array}$ & $\begin{array}{l}9.52^{\mathrm{a}} \\
(0.09)\end{array}$ & $\begin{array}{l}9.52^{\mathrm{a}} \\
(0.14)\end{array}$ & $\begin{array}{l}9.25^{\mathrm{b}} \\
(0.26)\end{array}$ \\
\hline
\end{tabular}

MC is moisture content; $a_{w}$ is water activity; $K$ is thermal conductivity; $R$ is thermal resistivity; $\alpha$ is thermal diffusivity; ER is expansion ratio; UD is unit density; BD is bulk density; WAI is water absorption index; WSI is water solubility index; PDI is pellet durability index; $\mathrm{L}^{*}$ is brightness /darkness; $\mathrm{a}^{*}$ is redness/greenness; $b^{*}$ is yellowness/blueness; Parentheses indicate \pm 1 standard deviation; Means followed by similar letters for a given dependent variable are not significantly different at $\mathrm{P}<0.05$ among treatments. 


\subsubsection{Moisture Content (MC)}

Water is one of the most important components of a biological substance playing crucial roles in forming the various properties such as mechanical, textural, and biological properties (Blahovec, 2007). It is also one of the main governing factors in food and feed processes like extrusion cooking process which affects the processing behavior and the final products qualities. In general, water or moisture content of a substance can exist in the form of bound, unbound, and free water (Mohsenin, 1986). In fact, the effect of free water content on the physical and biological properties of either raw and un-processed materials or processed and final products of a process is predominant. As per definition, free moisture content within a substance is the amount of moisture higher than the equilibrium water content which can be removed by drying under a certain relative humidity. Free water content of a substance can act as a plasticizer and impact the mechanical properties of a material such as viscoelasticity (Blahovec, 2007; Rosentrater et al., 2009). In extrusion processing, the synergistic effect of free water content of the ingredient and developed high temperature and high shear forces inside the extruder greatly can change the dough characteristics and extrudates physical properties like cohesiveness, water holding capacity, water stability, and storage stability (Chevanan et al., 2010; Rolfe et al., 2001). On the other hand, biochemical reactions among the water and chemical constituents of the blend in which starch, protein, and lipid contents play the most important roles, are profoundly influenced by the interaction effects of thermomechanial phenomena like heat transfer, shearing forces, and high pressure developed inside the barrel of the extruder during the process. The most effective reactions occurred during the process are starch gelatinization and protein denaturation which are drastically influenced by the amount and the source of these components (Mercier et al., 1989; Miller, 1985; Riaz, 2000). Due to the combination effects of these biochemical and thermomechanial alterations paired with a drastic and sudden pressure drop among the die entrance, die exit, and atmosphere, free water content of themolten dough evaporates and the latent heat of vaporization changes the internal structure of the exiting extrudate and eventual properties of the products (Friesen et al., 1992). Additionally, water content of a material is a function of the water activity of the material and the humidity of the surrounding air (Blahovec, 2007). Furthermore, the amount of free water content of a biological material plays a key role in the microbial growth and thus spoilage of the material (Abramovic \& Mojca, 2008).

As depicted in Table 4, inclusion of 20\% DDGS and 20\% HP-DDG resulted in 7\% and $36 \%$ decrease in MC of the extrudates compared to that of the control diet, respectively. Further increasing of the DDGS and HP-DDG to $40 \%$ dropped the MC of the extrudates by $31 \%$ and $45 \%$, respectively. No significant influence on MC of the products was observed between the diets containing 40\% DDGS and 20\% HP-DDG.

\subsubsection{Water Activity $\left(\mathrm{a}_{\mathrm{w}}\right)$}

Water activity is a crucial consideration for food and bio-based materials safety which serves for the explanation of the material's potential for microbial and fungal deterioration, and it is defined as the available water for microorganism use which affects the food safety and storage shelf life of the products (Abramovic \& Mojca, 2008). The water availability within a material can change with temperature variation as it can affect the water binding (Higl et al., 2007); thus, $\mathrm{a}_{\mathrm{w}}$ of a biological material can impact the enzyme activity and at some point, the nutritional value of the food product such as vitamin availability.

Using $40 \%$ DDGS, $20 \%$ and $40 \%$ HP-DDG in the diet formula reduced the $\mathrm{a}_{\mathrm{w}}$ of the extrudates by more than $50 \%$ compared to that of the control diet. Inclusion of $20 \%$ DDGS reduced the $\mathrm{a}_{\mathrm{w}}$ of the extrudates only by $10 \%$. The average water activities of all the extrudates lay below 0.25 , except that of diet 2 which was 0.43 .

\subsubsection{Thermal Properties}

Knowledge about the thermal properties of raw ingredients and final products of a thermal process can provide valuable information about the heat transfer through the system and the energy requirements needed at various stages of the thermal process. Three thermal properties of the extruded diets including thermal conductivity $(\mathrm{k})$, thermal diffusivity $(\alpha)$, and thermal resistivity $(R)$ were measured and the data are reported in Table 4 . Thermal conductivity of a material is a function of temperature gradient (Willix et al., 1998) and can be ascribed by the material ability to transfer the heat through itself without any motion. Sablani et al. (2002) suggested that $\mathrm{k}$ is a function of the moisture content, temperature, and apparent density for the baked products. It is believed that physiochemical reactions among the blend constituents, occurring above a certain temperature range, during a thermal processing, depending on the material nature can reduce $\mathrm{k}$ value of the heat-processed proteinaceous and starchy materials due to the protein denaturation and starch gelatinization and thus creation of highly cross-linked macromolecule structures (Fessas \& Schiraldi, 2000; Heldman, 2003). Addition of more hydrophobic ingredients in the raw blend can decrease the $\mathrm{k}$ value of the heat processed products such as extrudates. This explains why thermal properties of the extrudates are highly related to the initial components of 
the blend, process operational conditions, and internal structure of the extrudates (Alavi et al., 1999). In our extrusion study, neither inclusion of DDGS nor HP-DDG changed the $\mathrm{k}$ value of the extrudates compared to that of the control diet.

On the other hand, $\mathrm{R}$ is an indicator of a material ability to store the heat (Kawasaki \& Kawai, 2006) which can also vary as a function of material thickness and temperature gradient (Arambula-Villa et al., 2007). Addition of $20 \%$ and $40 \%$ DDGS decreased R of the extrudates by $5.0 \%$ and $3.6 \%$, respectively. While addition of $20 \%$ HP-DDG resulted in a $3.5 \%$ increase in the R, further increasing of HP-DDG to $40 \%$ did not have any significant impact on the heat storage capacity of the extrudates.Regarding the $\alpha$ values of the extruded diets, our observations indicated that inclusion of $20 \%$ DDGS decreased the $\alpha$ by nearly $6.3 \%$, while further addition of DDGS to $40 \%$ and inclusion of HP-DDG at both levels of $20 \%$ and $40 \%$ did not influence the $\alpha$ value, considerably compared to that of the control diet. The lowest $\alpha$ value of 0.15 was related to the less expanded extrudates containing 20\% DDGS with ER of 1.043. This was in agreement with our observations in another study conducted for soybean meal-based Yellow perch extruded diets (Fallahi et al., 2012). These results can be ascribed to the higher porosity of the more expanded extrudates and the higher thermal diffusivity of the trapped air in the pores compared to those of the protein and starch (Mariam et al., 2008). Ayadi et al. (2011a) suggested that the low $\mathrm{k}$ value and $\alpha$ value of the raw blends may affect the extrusion processing adversely due to a longer time required for heat transfer during the cooking process. On the other hand, the substances with low heat conductivity and diffusivity may be more heat-stable and thus less affected by external thermal sources. They also believed that, the low values of $\mathrm{k}, \mathrm{R}$, and $\alpha$ can impact the required time for cooling and/or drying of the extrudates. In general, knowledge of the thermal properties of the ingredients can be helpful to control the extrusion operational conditions and to manipulate the product physical properties such as expansion ratio and density.

\subsubsection{Expansion Ratio (ER)}

One of the most critical factors indicating the physical quality of the aquafeed is the expansion ratio influencing the floatability of the feed. As depicted in Table 4, inclusion of $20 \%$ and $40 \%$ DDGS resulted in a significant decrease in extrudate ER by nearly $11.6 \%$ and $4.2 \%$, compared to that of the control diet, respectively. Also, it is clear that inclusion of HP-DDG at both levels of $20 \%$ and $40 \%$ led to the production of more expanded and floatable extrudates compared to those extrudates including DDGS; however, no significant change in ER values of HP-DDG included extrudates were observed compared to that of the control diet. The higher ER of the extrudates from Diet 3 and 4 could be due to the lower crude fiber content of the HP-DDG compared to that of DDGS and consequently less water desorption by the HP-DDG included extrudates. All the produced extrudates were floated for more than 25 min (Figure 1). Generally, there is a positive relation between an extrudate's ER and floating property (Rolfe et al., 2001; Rosentrater et al., 2009). The more expended extrudates imply the more gelatinization of the starch component of the extruding blend which can result in a crispier and easier to digest extrudates (Rout, 1997). It is expected that, as the starch content is decreased, the obtained ER during extrusion is reduced as well (Chevanan et al., 2009). Obtaining a desired ER is one of the challenging issues when corn ethanol coproducts are used as the fishmeal replacers (Chevanan et al., 2009). In fact, numerous factors may influence the extent of expansion during the extrusion processing. For instance, the magnitude of the pressure gradient generated at the die exit during the evaporation can impact the ER of the extruding melted dough; this pressure gradient causes water phase transition and indeed is a driving force for expansion phenomenon and formation of puffy texture in the extrudates (Alves et al., 1999; Lam \& Flores, 2003; Moore, 1990); however, its magnitude is proportional to the entire feed constituents, dough moisture content, and die configuration (Bouzaza et al., 1996; Chevanan et al., 2007a; Tumuluru \& Sokhansanj, 2008). Additionally, feeding rate, rheological behavior of the extruding dough, residence time (Fan et al., 1994; Chevanan et al., 2007a; Mitchell et al., 1994), and extrudates mass flow rate (Chevanan et al., 2007a; Tumuluru \& Sokhansanj, 2008) can affect the extent of developed pressure gradient at the die exit. On the other hand, dynamic flow of the dough inside the die is drastically influenced by the temperature and the present water content. The high temperature and lubricant effect of water increase the molecules mobility and thus the melted dough exhibits pseudoplastic behavior leading to a substantial decrease in the apparent viscosity of the extruding dough which affects the extent of pressure release and ultimately reduces ER of the finished product (Chevanan et al., 2007a; Mjoun \& Rosentrater, 2011; Rosentrater et al., 2005). While the higher the starch content results in a more expanded extrudates due to starch gelatinization and elastic characteristic of the dough inside the barrel and consequent pressure rise at the die exit (Ibanoglu et al., 1996; Kokini et al., 1992; Lin et al., 2000; Nielsen, 1976; Sokhey et al., 1994); the more incorporation of protein in the blend ingredients results in production of extrudates with more porous texture mainly because ofthe protein denaturation and plastic characteristic of the melted dough inside the extrusion 
barrel (Chevanan et al., 2007a; Sandra \& Jose 1993; Singh et al., 1991). The ability of the protein component of the blend in distribution of water inside its macromolecular structure can also affect the ER of the extrudates (Deshpande and Poshadri, 2011). Also, applying extrusion conditions with the higher barrel temperature causes more excretion of super-heated steam and subsequently more expanded products will be produced (Kim et al., 1989).

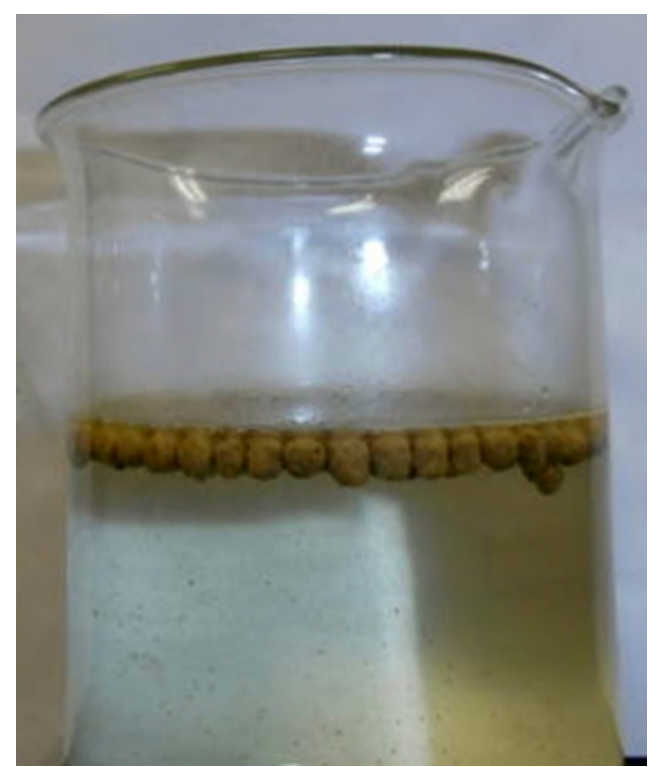

Figure 1. All extrudates from diet 1 (20\% DDGS), diet 2 (40\% DDGS), diet 3 (20\% HP-DDG), and diet 4 (40\% HP-DDG) floated for more than $25 \mathrm{~min}$

\subsubsection{Unit Density (UD)}

UD is the other important physical properties of the extruded aquafeed which is directly related to the ER of the extrudates and thus impacts the floatability of the feed (Chevanan et al., 2007a, 2009; Colonna et al., 1989). Therefore, UD of the extruded products can be influenced by the factors impacting ER. Several extrusion studies have reported that there is a negative correlation between the barrel temperature during the extrusion process and UD of the extruded product (Bhattacharya \& Hanna, 1986; Harper et al., 1981) which implies the pseudoplastic behavior of the melted dough, decrease in apparent viscosity, less pressure gradient at the die exit, subsequent increase in expansion, and thus reduction in UD of the extrudates. Their observations were in agreement with what Chevanan et al. (2007a) reported regarding the inverse effect of barrel temperature on UD of the DDGS-based extrudates. Comparison of the UD of the extrudates from the four experimental diets to that of the control diet, exhibited that DDGS inclusion at level of $20 \%$ had the greatest effect on UD and led to a significant increase in UD value by $21.20 \%$ where further increasing of DDGS to $40 \%$ and inclusion of HP-DDG at both levels of $20 \%$ and $40 \%$ slightly increased the UD values of the extrudates which were not statistically considerable (Table 4). As shown, the minimum UD value of $731.70\left(\mathrm{~kg} / \mathrm{m}^{3}\right)$ was attained for the control diet while the highest value of $886.65\left(\mathrm{~kg} / \mathrm{m}^{3}\right)$ was related to the extrudates from diet 1 (Table 4). Overall, UD values were less than that of the water which confirms the buoyancy of the extrudates.

\subsubsection{Bulk Density (BD)}

As the other key physical properties of biological products, BD always has been one of the major factors to consider. It is very important for assessing the appropriate packaging, the required storage space for warehousing and transportation of the products as it indicates the mass content of a given volume of product (Guy, 2001; Rosentrater, 2006). From an economic point of view, the higher the bulk density, the better, because it reduces the packaging, storage and transportation costs for a certain mass of product. Similar to UD and ER, BD of the extrudates is influenced by the effect of extrusion processing conditions on thermodynamic characteristics of the ingredient mixture. For example, screw speed, barrel temperature, die dimension, and feed moisture content are some of these parameters that significantly influence the extruding dough temperature, gradient pressure at die section, dough density, dough viscosity, and consequently extrudates UD and BD values (Tumuluru \& Sokhansanj, 2008). 
As shown in Table 4, the highest BD of $666.91\left(\mathrm{~kg} / \mathrm{m}^{3}\right)$ was observed for the extrudates with $20 \%$ DDGS inclusion (Diet 1) with a $16.6 \%$ increase compared to that of the control diet. While further inclusion of DDGS to $40 \%$ led to only $5 \%$ increase in BD value of the extrudates. There was no significant difference among the BD values of products with $20 \%$ and $40 \%$ HP-DDG and that of the control diet. These observations for the decreasing and increasing values of ER and UD of the extrudates with $20 \%$ DDGS inclusion confirm the inverse and direct relation of BD to ER and UD, respectively. As shown in the results, the most floatable extrudates had the lowest $\mathrm{BD}$ and UD values. On the other hand the higher the BD the better the products; therefore, making a balance between the desired ER and BD values of the products is the other major factors inaquafeed industry that need to be considered (Mjoun \& Rosentrater, 2011).

\subsubsection{Water Absorption and Water Solubility Indices (WAI, WSI)}

Table 4 shows that the water absorption index values were more for the extrudates made from diets containing DDGS than that of the extrudates produced from HP-DDG based diets. It could be due to higher starch content of the DDGS. Incorporation of $20 \%$ DDGS yielded an $11 \%$ increase in WAI and further increasing of DDGS to $40 \%$ raised the WAI by nearly $21 \%$, while using $20 \%$ and $40 \%$ HP-DDG reduced the WAI by $30 \%$ and $26 \%$ compared to that of the control diet, respectively. The maximum WAI of 4.21 was observed for the extrudate made from diet 2. No significant difference was observed between the WAI values of the products produced from diet 3 and 4. Looking at data presented in Table 4, the extrudates with higher BD also had relatively higher WAI. It was in contrast with our observations in a previous twin-screw extrusion study performed for soy-protein based Yellow perch diet (Fallahi et al., 2012). Also, there was no relation between the ER and WAI of the extrudates. While, in another study conducted by Adeparusi and Famurewa (2011), a direct relation between the ER and WAI of the extrudates was reported. They suggested that the more expanded extrudates can absorb more water. Theoretically, the ability of the extrudates in absorption of water can be attributed to the un-damaged portion of starch content of the feed blend which was not influenced by the extrusion processing (Chevanan et al., 2007a; Govindasamy, 1996; Mason \& Hoseney, 1986). In other words, the greater the WAI of the extrudates implies lesser change in native structure of the starch components of the feed blend and consequently, lesser depolimerization of amylose and amylopectin molecules during extrusion processing. However, many researchers suggested that any structural modification such as starch gelatinization and protein denaturation in the macromolecule components of the blend can cause significant change in WAI of the extrudates (Badrie \& Mellowes, 1991; Chevanan et al., 2007a; Rosentrater et al., 2009). Additionally, intensity of heat treatment causes those water binding sites on the side chain of the protein molecules which were blocked by the lipid to be more available to the water and thus the water absorption increased (Sathe et al., 1982).

In terms of the WSI, we observed that inclusion of DDGS at both levels of $20 \%$ and $40 \%$ slightly increased the WSI compared to that of the control diet while incorporation of $20 \%$ HP-DDG and $40 \%$ HP-DDG significantly increased the WSI by approximately 13\% and 9\%, respectively. Extrudates produced from diet 3 and 4 with HP-DDG inclusion exhibited to have higher WSI values compared to those of the diet 1 and 2 produced from C-DDG based feed blends. As it was expected (Anderson et al., 1982), an inverse relation between the WSI and WAI values of the extrudates was observed. Since in contrast to WAI, the magnitude of the WSI of the extrudates reflects the percentage of the portions of starch and/or protein molecules of the feed blend which were drastically degraded during the extrusion processing (Colonna Mercier, 1983; Govindasamy, 1996). The extrudates with the highest WSI of $16.70(\%)$ had the lowest WAI of $2.45(-)$ which were produced from diet 3 with $20 \%$ HP-DDG. In fact, the nature of the protein and starch components of the feed blend paired with the combination effects of extrusion processing parameters such as barrel temperature, developed shearing forces, pressure, and even the physical configurations of the screw, barrel chamber, and the die section influence the extent of depolimerization and water plasticization of these macromolecules and thus alter the WSI and WAI values of the extrudates (Anderson et al., 1982; Menegassi et al., 2011).

\subsubsection{Pellet Durability Index (PDI)}

Durability index of the extruded feed is the other physical properties predicting the mechanical strength of the extrudates against the abrasive forces specifically during the transportation, storage and feeding. Indeed, engineering the PDI greatly helps to reduce the economic losses that may occur due to nutrient loss or pond pollution as a result of using low quality extrudates with mechanically weak structure. Physiochemical transformation of starch component of the feed blend in response to the variation of extrusion processing condition significantly impacts the cohesiveness and durability of the extruded blends against the external pressures (Chevanan et al., 2007a; Colonna et al., 1989; Rosentrater et al., 2009). As depicted in Table 4, all measured PDIs lay above $99 \%$, irrespective of protein source types and their inclusion levels. The diet with $20 \%$ DDGS had the lowest PDI of $99.33 \%$ and the diet with $40 \%$ HP-DDG reached the highest PDI of $99.64 \%$; 
however, there were no statistical differences between the PDI values of the experimental diets compared to that of the control diet. Similar results were attained by Rosentrater and Tulbek (2010), Ayadi et al. (2011a, 2011b, and 2011c), and Fallahi et al. (2011).

4.2.9 Color ( $\mathrm{L}^{*}, \mathrm{a}^{*}$, and $\left.\mathrm{b}^{*}\right)$

Color is another physical property of the food products which can be used for indirectly verification of safety (Friedman, 1996) and nutritional quality (Berset, 1989; Dahl \& Villota, 1991; Rosentrater et al., 2005) of the food. Color of biological products is drastically influenced during the thermal processing mainly due to the non-enzymatic browning reaction (Maillard) which leads to protein deterioration. In extrusion processing, high temperature and semi-dry condition favors the browning reaction which results in amino acid destruction and unavailability of some of essential amino acids such as lysine and tryptophan (Hurrell et al., 1979). The required reduced sugar for this process is provided by hydrolysis and dextrinization of starch component of the feed blend induced by mechanical shearing (Shagun \& Harper, 1980). Other factors such as screw configuration and size of the die opening which impact the extent of shear forces can cause significant physico-chemical alteration in protein, formation of deleterious compounds, and change the extrudate color (Friedman, 1996; Mega \& Cohen, 1978). As the amino acid lysine produces the most color when reacting with sugars, change of extrudate color can be attributed to the formation of unusable blocked lysine (Chevanan et al., 2007a) due to crosslinking the protein (Feeney, 1980; O’Brien \& Morrisey, 1989). Guerra-Hernandez et al. (1999) claimed that the intensity of the browning reaction can be quantified by measuring the color change of the heat treated products compare to raw materials.

The effects of each diet on color of the extrudates are provided in Table 4. In general, inclusion of 20\% DDGS resulted in $7.6 \%, 12.2 \%$, and $12.9 \%$ decrease in lightness $\left(\mathrm{L}^{*}\right)$, redness $\left(\mathrm{a}^{*}\right)$, and yellowness $\left(\mathrm{b}^{*}\right)$ of the extrudates compared to those of the control diet, respectively. Further incorporation of DDGS to $40 \%$ led to a $2.8 \%$ and $5.8 \%$ increase in $\mathrm{L}^{*}$ and $\mathrm{b}^{*}$ values, respectively, while it did not show any effect on $\mathrm{a}^{*}$ of the produced extrudates compared with those of the control diets. Also, inclusion of $20 \%$ and $40 \%$ HP-DDG yielded an increase of $3.5 \%, 1.8 \%, 5.9 \%$, and $2.9 \%$ in lightness and yellowness but a decrease of $4.5 \%$ and $7.3 \%$ in redness of the extrudates, compared to those of the control diet, respectively.

\section{Conclusions and Future Study}

The results from this twin-screw extrusion study revealed that, replacing fishmeal with HP-DDG at both levels of 20 and $40 \%$ led to production of extrudates with higher ER and WSI values but lower UD, BD, and WAI values compared to those of the diets produced with $20 \%$ or $40 \%$ DDGS incorporation. Using $20 \%$ DDGS resulted in production of the extrudates with minimum ER, $\mathrm{L}^{*}, \mathrm{a}^{*}$, and $\mathrm{b}^{*}$ but maximum UD and BD values compared to those of the fish meal-based diet. Extrudates with 20\% HP-DDG inclusion appeared to have the highest darkness value $\left(\mathrm{L}^{*}\right)$. Increasing inclusion levels of HP-DDG did not show any effect on UD or ER of the products. Clearly, the inclusion of HP-DDG at both levels of $20 \%$ and $40 \%$ led to the production of more expanded and floatable extrudates compared to those extrudates contained DDGS. All the extrudates of four experimental diets exhibited to have excellent durability index indicating that DDGS and HP-DDG inclusions do not have ill effects on the extruded diet resistance against the abrasive forces. Water activity of all the extrudates lay below 0.45 . Low $\mathrm{a}_{\mathrm{w}}$ of the produced extrudates guaranteed a stable product with long storage stabilities. Overall, DDGS and HP-DDG up to $40 \%$ could be used to produce quality extrudates with acceptable physical properties for rainbow trout. This study was a positive step toward the utilization of HP-DDG based feed in aquaculture industry.

Future research should concentrate on examining the effects of both extrusion processing and higher levels of HP-DDG on rainbow trout feeds, as well as nutritional efficacy by conducting feeding trials.

\section{Acknowledgements}

The authors thank the Agricultural Experiment Station, South Dakota State University, and the North Central Agricultural Research Laboratory, USDA-ARS, Brookings, South Dakota, for funding, facilities, equipment and supplies. Furthermore, the cooperation and assistance of Sharon Nichols, Christine Wood, Mike Barnes, and Riley Morgan is greatly appreciated.

\section{References}

Aas, T. S., Hatlen, B., Grisdale-Helland, B., Terjesen, B. T., Bakke-McKellep, A. M., \& Helland. S. J. (2006). Effects of diets containing bacterial protein meal on growth and feed utilization in rainbow trout (Oncorhynchus mykiss). Aquac., 261, 357-368. 
Abo-State, H. A., Tahoun, A. M., \& Hammouda, Y. A. (2009). Effect of replacement of soybean by HPDDG combined with commercial phytase on Nile tilapia (Oreochromis niloticus) fingerlings growth performance and feed utilization. American-Eurasian Journal of Agriculture and Environmental Science, 5, 473-479.

Abramovic, H., \& Jamnik, M. (2008). Water activity and water content in Slovenian honeys. Food Control, 19, 1086-1090.

ADCP (Aquaculture Development and Coordination Programme). (1983). Fish feeds and feeding in developing countries: an interim report on the ADCP Feed Development Programme. FAO Project INT/81/031 Aquaculture Development and Coordination Programme, FAO Field Document No. ADCP/REP/83/18,FAO, Rome, p. 100.

Adeparusi, E .O., \& Famurewa, J. A. V. (2011). Water Temperature and Surface Coating Effect on Floatability, Water Absorption and Thickness Swelling of Feed. J. Agric. Sci., 3(4), 254-260.

AgMRS. (2011). Estimated U. S. Dried Distillers Grains with Solubles (DDGS) Production \& Use. Retrieved June 4, 2011 from http://www.extension.iastate.edu/agdm/crops/outlook/dgsbalancesheet.pdf

Alavi, S. H., Gogoi, B. K., Khan, M., Bowan, B. J., \& Rizvi, S. S. H. (1999). Structural properties of protein stabilized starch-based supercritical fluid extrudates. Food Res. Intel., 32, 107-118. http://dx.doi.org/10.1016/S0963-9969(99)00063-0

Ali, S. A. (1988). Water stability of prawn feed pellets prepared using different binding materials with special reference to tapioca. Ind. J. Fish, 35(1), 46-51.

AllAboutFed.net. (2010). DDGS in fish feed. Retrieved June 21, 2012 from http://www.allaboutfeed.net/allabouts/aquafeed/ddgs-in-fish-feed-id2453.html

Alves, R. M. L., Grossmann, M. V. E., \& Silva, R. S. F. (1999). Gelling properties of extruded yam (Dioscorea alota) starch. Food Chem., 67, 123-127. http://dx.doi.org/10.1016/S0308-8146(99)00064-3

Anderson, R. A. (1982). Water absorption and solubility and amylograph characteristics on roll cooked small grain products. Cereal Chem., 59, 265-269.

Anderson, R. A., Conway, H. F., Pfeifer, V. F., \& Griffin, L. E. (1969). Gelatinization of corn grits by roll and extrusion cooking. Cereal Sci. Today, 14, 4-7.

Arámbula-Villa, G., Guitiérrez-Árias, E., \& Moreno-MartÍnez, E. (2007). Thermal properties of maize masa and tortillas with different components from maize grains, and additives. Journal of Food Eng., 80(1), 55-60. http://dx.doi.org/10.1016/j.jfoodeng.2006.05.004

Ayadi, F. Y., Muthukumarappan, K. Rosentrater, K. A., \& Brown, M. L. (2011a). Single-screw extrusion processing of distillers dried grains with solubles (DDGS)-based yellow perch (Perca flavescens) feeds. Cereal Chem., 88, 179-188.

Ayadi, F. Y., Muthukumarappan, K., Rosentrater, K. A., \& Brown, M. L. (2011c). Twin-screw extrusion processing of rainbow trout (Oncorhynchus mykiss) feeds using various levels of corn-based distillers dried grains with solubles (DDGS). Cereal Chem., 88, 363-374.

Ayadi, F. Y., Rosentrater, K. A., Muthukumarappan, K., \& Brown, M. L. (2011b). Twin-screw extrusion processing of distillers dried grains with solubles (DDGS)-based yellow perch (Perca flavescens) feeds. Food \& Bioprocess Technol.

Badrie, N., \& Mellowes, W. (1991). Effect of extrusion variables on cassava extrudate. J. Food Sci., 56(5), 1334-1337.

Barnes, M. E., Brown, M. L., \& Rosentrater, K. A. (2012). Initial observations on the inclusion of high protein distillers dried grain into rainbow trout diets. The Open Fish Science Journal, 5, 21-29.

Belyea, R. L., Eckhoff, S. R., Wallig, M. A., \& Tumbleson, M. E. (1998). Variability in the nutritional quality of distillers solubles. Bioresource Technol., 66, 207-212.

Belyea, R. L., Rausch, K. D., \& Tumbleson, M. E. (2004). Composition of corn and distillers dried grains with solubles from dry grind ethanol processing. Bioresource Technol., 94, 293-298.

Berset, C. (1989). Color. In C. Mercier, P. Linko, \& J. M. Harper (Eds.), Extrusion Cooking (pp. 371-385). American Association of Cereal Chemists International. St. Paul, MN.

Blahovec, J. (2007). Role of water content in food and product texture. Int. Agrophys., 21(3), 209-215. 
Bouzaza, D., Arhaliass, A., \& Bouvier, J. M. (1996). Die design and dough expansion in low moisture extrusion-cooking process. J. Food Eng., 29, 139-152.

Cain, K. D., \& Garling, D. L. (1995). Pre-treatment of soybean meal with phytase for salmonid diets to reduce phosphorus concentrations in hatchery effluents. Prog. Fish-Cult., 57, 114-119.

Case, S. E., Hamann, D. D., \& Schwartz, S. J. (1992). Effect of starch gelatinization on physical properties of extruded wheat and corn based products. Cereal Chem., 69, 401-404.

Cavalcanti, W. B., \& Behnke, K. C. (2005a). Effect of composition of feed model system on pellet quality: a mixture experimental approach. I. Cereal Chem., 82, 455-461. http://dx.doi.org/10.1094/CC-82-0455

Cavalcanti, W. B., \& Behnke, K. C. (2005b). Effect of composition of feed model systems on pellet quality: a mixture experimental approach. II. Cereal Chem., 82, 462-467. http://dx.doi.org/10.1094/CC-82-0462

Cheftel, J. C. (1986). Nutritional effects of extrusion-cooking. Food Chem., 20, 263-283.

Cheng, Z. J., Hardy, R. W., \& Blair, M. (2003). Effects of supplementing methionine hydroxyl analogue in soybean meal and distillers dried grain-based diets on the performance and nutrient retention of rainbow trout (Oncorhynchus mykiss (Walbaum)). Aquacult Res., 34, 1303-1310.

Cheng, Z. J., \& Hardy, R. W. (2002). Effect of phytase on apparent digestibility coefficients of nutrients and energy availability of barley, canola meal, wheat and wheat middlings measured in vivo using rainbow trout (Oncorhynchus mykiss). Aquacult. Nutr., 8(4), 271-277.

Cheng, Z. J., \& Hardy, R. W. (2004). Nutritional value of diets containing distiller's dried grain with solubles for rainbow trout, Oncorhynchus mykiss. Journal of Applied Aquaculture, 15, 101-113.

Chevanan, N., Muthukumarappan, K., \& Rosentrater, K. A. (2009). Extrusion studies of aquaculture feed using distillers dried grains with solubles and whey. Food and Bioprocess Technol., 2(2), 177-185. http://dx.doi.org/10.1007/s11947-007-0036-8

Chevanan, N., Muthukumarappan, K., Rosentrater, K. A., \& Julson, J. L. (2007a). Effect of die dimensions on extrusion processing parameters and properties of DDGS-based aquaculture feeds. Cereal Chem., 84, 389-398.

Chevanan, N., Rosentrater, K. A., \& Muthukumarappan, K. (2007b). Twin screw extrusion processing of feed blends containing distillers dried grains with solubles (DDGS). Cereal Chem., 84, 428-436.

Chevanan, N., Rosentrater, K. A., \& Muthukumarappan, K. (2008). Effect of DDGS, moisture content, and screw speed on physical properties of extrudates in single-screw extrusion. Cereal Chem., 85, 132-139.

Chevanan, N., Rosentrater, K. A., \& Muthukumarappan, K. (2010). Effects of processing conditions on single screw extrusion of feed ingredients containing DDGS. Food Bioprocess Technol., 3, 111-120.

Chhron, L., \& Mediha, Y. (2008). Distillers dried grains with solubles as an alternative protein source in fish feeds. 8th International Symposium on Tilapia in Aquaculture 67-82. Retrieved from http://ag.arizona.edu/azaqua/ista/ISTA8/ChhornLim.pdf. Accessed June 6, 2011

Colonna, P., \& Mercier, C. (1983). Macromolecular modifications of manioc starch components by extrusion-cooking with and without lipids. Carbohydr. Polym., 3(2), 87-108. http://dx.doi.org/10.1016/0144-8617(83)90001-2

Colonna, P., Tayeb, J., \& Mercier, C. (1989). Extrusion cooking of starch and starchy products. In L. H. Mercier, (Ed.), Extrusion Cooking. St. Paul, Minnesota, USA: American Association of Cereal Chemists.

Cooper, G. (2006). A brief, encouraging look at "theoretical" distillers grains markets. Distillers Grains Quarterly, first quarter. Retrieved from http://ethanolproducer. com/dgq/article-print.jsp?article_id=1176

Coyle, S. D., Mengel, G. J., Tidwell, J. H., \& Webster, C. D. (2004). Evaluation of growth, feed utilization, and economics of hybrid tilapia, Oreochromis niloticus $\times$ Oreochromis aureus, fed diets containing different protein sources in combination with distillers dried grains with solubles. Aquaculture Research, 35, 365-370.

Dahl, S. R., \& Villota, R. (1991). Effect of thermal denaturation on the texturization of soybean protein through twin-screw extrusion. J. Can. Inst. Sci. Technol., 24, 143-150.

Deshpande, H. W., \& Poshadri, A. (2011). Physical and sensory characteristics of extruded snacks prepared from Foxtail millet based composite flours. Food Res. Int., 18, 751-756. 
Fallahi, P., Muthukumarappan, K., Rosentrater, K. A., \& Brown, M. L. (2012). Twin-screw extrusion processing of vegetable-based protein feeds for yellow perch (Perca flavescens) containing distillers dried grains, soy protein concentrate, and fermented high protein soybean meal. Journal of Food Research. http://dx.doi.org/10.5539/jfr.v1n3p230

Fallahi, P., Rosentrater, K. A., Muthukumarappan, K., \& Tulbek, M. (2011). Effects of conditioner steam, extruder water and screw speed on physical properties of DDGS-based extrudates in twin-screw extrusion, ASABE Annual International Meeting 2011, August 7 - 10, Louisville, Kentucky, Paper No. 1110887.

Fan, J., Mitchell, J. R., \& Blanshard, J. M. V. (1994). A computer simulation of the dynamics of bubble growth and shrinkage during extrudate expansion. J. Food Eng., 23(3), 337-356. http://dx.doi.org/10.1016/0260-8774(94)90058-2

Faubion, J. M., Hoseney, R. C., \& Seib, P. A. (1982). Functionality of grain components in extrusion. Cereal Foods World, 27, 212-216.

FDS. (1994). Feed Development Section 1994: Feeds and feeding of milkfish, Nile tilapia, Asian sea bass, and tiger shrimp. Aquaculture Extension Manual No. 21, Southeast Asian Fisheries Development Center, SEAFDEC AquacultureDepartment, Tigbauan, Iloilo, Philippines, p. 97.

Feeney, R. E. (1980). Overview on the chemical deteriorative changes of proteins and their consequences. In: Whitaker \& Fujimaki (Eds.), Chemical Deterioration of Proteins (pp. 1-47). ACS Symposium Series 123, ACS publications.

Fessas, D., \& Schiraldi, A. (2000). Starch gelatinization kinetics in bread dough DSC investigations on simulated baking processes. J. Therm. Anal. Calorim., 61, 411-423.

Fowler, L. G., \& Banks, J. L. (1976). Fish meal and wheat germ substitutes in the Abernathy diet. Prog Fish-Cult., 38, 127-30.

Friedman, M., (1996). Food browning and its prevention: an overview. J. Agric. Food Chem., 44(3), 631-653.

Friesen, K. G., Nelssen, J. L., Behnke, K. C., \& Goodband, R. D. (1992). Ingredient processing: Improving pig feed by extrusion. Feed Management, 43, 33-38.

GAA. (2000). Global Aquaculture Alliance 2000. Retrieved from June 29, 2012 http://www.ftai.com/articles/GAAManciDec00.pdf

Gokulakrishnan, P., \& Bandyopadhyay, S. (1995). Formulation and characterization of some pelleted feeds for Penaeus monodon. Fish. Technol., 32(1), 19-24.

Govindasamy, S., Campanellab, O. H., \& Oatesa, C. G. (1996). High moisture twin-screw extrusion of sago starch: 1. Influence on granule morphology and structure. Carbohydr. Polym., 30(4), 275-286. http://dx.doi.org/10.1016/S0144-8617(96)00024-0.

Guy, R. C. E. (2001). Raw materials for extrusion cooking. In R. C. E. Guy (Ed.), Extrusion Cooking Technologies and Applications (pp. 5-28, 89). Cambridge, UK: Woodhead Publishing Limited.

Ham, G. A., Stock, R. A., Klopfenstein, T. J., Larson, E. M., Shain, D. H., \& Huffman, R. P. (1994). Wet corn distiller's byproducts compared with dried corn distillers grains with solubles as a source of protein and energy for ruminants. J. Anim. Sci., 72, 3246.

Hardy, R. W. (2010). Utilization of plant proteins in fish diets: effects of global demand and supplies of fishmeal. Aquac. Res., 41, 770-776.

Hardy, R. W., \& Masumoto, T. (1990). Specifications for marine by-products for aquaculture. In S. Keller (Ed.), Proc. Int. Conf. on Fish By-products (pp. 109-120). Anchorage, AK: Alaska Sea Grant College Program.

Heldman, D. R. (2003). Encyclopedia of Agricultural, Food, and Biological Engineering (pp. 1004). Boca Raton, FL: CRC Press, Technology and Engineering.

Higl, B., Kurtmann, L., Carlsen, C. U., Ratjen, J., Först, P., Skibsted, H. L., ... Risbo, J. (2007). Impact of water activity, temperature, and physical state on the storage stability of Lactobacillus paracasei ssp. paracasei freeze-dried in a lactose matrix. Biotechnol. Progr., 23(4), 794-800.

Hughes, S. G. (1987). Distillers products in salmonid diets. Proc. Distillers Feed Conf., 42, $27-31$.

Hurrell, R. F., Lerman, P., \& Carpenter, K. J. (1979). Reactive lysine in food stuff as measured by a rapid dye-binding procedure. J. Food Sci., 44, 1221. 
Ibanoglu, S., Paul, A., \& George, D. H. (1996). Extrusion of tarhana: Effect of operating variables on starch gelatinization. Food Chem., 57, 541-544. http://dx.doi.org/10.1016/S0308-8146(96)00047-7

Jacques, K. A., Lyons, T. P., \& Kelsall, D. R. (2003). The Alcohol Textbook (4th ed). Nottingham University Press, Nottingham, UK.

Jauncey, K., \& Ross, B. (1982). Nutritional terminology. A Guide to Tilapia Feeds and Feeding (pp. 95-100). Scotland: Institute of Aquaculture, University of Stirling.

Kawasaki, T., \& Kawai, S. (2006). Thermal insulation properties of wood-based sandwich panel for use as structural insulated walls and floors. Wood Sci., 52(1), 75-83. http://dx.doi.org/10.1007/s10086-005-0720-0

Kiang, M. J. (1998). Principles of aquaculture feed production by cooking extruder, in: Advances in Extrusion Technology (pp. 107-113). Technomic Publishing Company, Inc., Lancaster, PA.

Kim, C. H., Maga, J. A., \& Martin, J. T. (1989). Properties of extruded dried distillers grains (DDG) and flour blends. J. Food Process. Pres., 13(3), 219-231. http://dx.doi.org/10.1111/j.1745-4549.1989.tb00102.x

Kokini, L. J., Ho, C. T., \& Karwe, M. V. (1992). Food Extrusion Science and Technology. New York, NY: Marcel Dekker.

Lam, C. D., \& Flores, R. A. (2003). Effect of particle size and moisture content on viscosity of fish feed. Cereal Chem., 80, 20-24.

Li, M. H., Robinson, E. H., Oberle, D. F., \& Lucas, P. M. (2010). Effects of various corn distillers by-products on growth, feed efficiency, and body composition of channel catfish, Ictalurus punctatus. Aquacult. Nutr., 16, 188-193. http://dx.doi.org/10.1111/j.1365-2095.2009.00650.x

Lim, C., \& Dominy, W. G. (1991). Proceedings of the Aquaculture Feed Processing and Nutrition Workshop (pp. 163-172). Akiyama, D.M., Tan, R.K.H. (Eds), American Soybean Association. Singapore.

Lim, C., Garcia, J. C., Yildirim-Aksoy, M., Klesius, P. H., Shoemaker, C. A., \& Evans, J. J. (2007). Growth response and resistance to Streptococcus iniae of Nile tilapia, Oreochromis niloticus, fed diets containing distiller's dried grains with solubles. J. World Aquacult. Soc., 38(2), 231-237.

Lim, C., Yildirim-Aksoy, M., \& Klesius, P. H. (2009). Growth response and resistance to Edwardsiella ictaluri of channel catfish, Ictalurus punctatus, fed diets containing distiller's dried grains with solubles. $J$. World Aquacult. Soc., 40, 182-193.

Lin, S., Hsieh, F., \& Huff, H. E. (1998). Effects of lipids and processing conditions on lipid oxidation of extruded dry pet food during storage. Anim. Feed Sci. Tech., 71, 283-294. http://dx.doi.org/10.1016/S0377-8401(97)00157-0

Lin, S., Huff, H. E., \& Hsieh, F. (2000). Texture and chemical characteristics of soy protein meat analog extruded at high moisture. J. Food Sci., 65, 264-269. http://dx.doi.org/10.1111/j.1365-2621.2000.tb15991.x

Maga, J. A., \& Cohen, H. R. (1978). Effect of extrusion parameters on certain physical, sensory and nutritional properties of potato flakes. Lebensm. Wiss Technol., 11, 195-197.

Mariama, I., Choa, K. Y., \& Rizvi, S. S. H. (2008). Thermal properties of starch-based biodegradable foams produced using supercritical fluid extrusion (SCFX). Int. J. Food Prop., 11(2), 415-426.

Marine Aquaculture Task Force. (2007). Sustainable Marine Aquaculture: Fulfilling the Promise (pp. 93). Managing the Risks, Takoma Park, MD. Retrieved January, 2007 from http://seafoodforthefuture.org/aquaculture-efficiency-and-feeds/

Mason, W. R., \& Hoseney, R. C. (1986). Factors affecting the viscosity of extrusion cooked wheat starch. Cereal Chem., 63(5), 436-441.

Mathew, J. M., Hoseney, R. C., \& Faubion, J. M. (1999a). Effects of corn sample, mill type, and particle size on corn curl and pet food extrudates. Cereal Chem., 76, 621-624. http://dx.doi.org/10.1094/CCHEM.1999.76.5.621

Mathew, J. M., Hoseney, R. C., \& Faubion, J. M. (1999b). Effects of corn hybrid and growth environment on corn curl and pet food extrudates. Cereal Chem., 76, 625-628. http://dx.doi.org/10.1094/CCHEM.1999.76.5.625

Mathew, J. M., Hoseney, R. C., \& Faubion, J. M. (1999c). Effect of corn moisture on the properties of pet food extrudate. Cereal Chem., 76, 953-956. http://dx.doi.org/10.1094/CCHEM.1999.76.6.953 
Menegassia, B., Pilosofb, A. M. R., \& José, A. G. (2011). Comparison of properties of native and extruded amaranth (Amaranthus cruentus L. - BRS Alegria) flour. LWT - Food Sci. Technol., 44(9), 1915-1921. http://dx.doi.org/10.1016/j.lwt.2011.04.008

Mercier, C., Linko, P., \& Harper, J. M. (1989). Extrusion cooking of starch and starchy products. In Extrusion Cooking (pp. 247-319). American Association of Cereal Chemists, Inc., St. Paul, MN, USA.

Metts, L. S., Thompson, K. R., Xiong, Y., Kong, B., Webster, C. D., \& Brady, Y. (2007). Use of alfalfa hay, compared to feeding practical diets containing two protein levels, on growth, survival, body composition, and processing traits of Australian red claw crayfish, Cherax quadricarinatus, grown in ponds. J. World Aquacult. Soc., 38(2), 218-230.

Miller, R. C. (1985). Low moisture extrusion: Effects of cooking moisture on product characteristics. J. Food Sci., 50, 249-253.

Mitchell, J. R., Fan, J., \& Blanshard, J. M. V. (1994). The shrinkage domain. Extrusion Communiqué, 10-12.

Mjoun, K., \& Rosentrater, K. A. (2011). Extruded aquafeeds containing distillers dried grains with solubles: effects on extrudate properties and processing behaviour. J. Sci. Food Agr., 91(15), 2865-2874. http://dx.doi.org/10.1002/jsfa.4536

Mohsenin, N. N. (1986). Physical Properties of Plant and Animal Materials: Structure, Physical Characteristics and Mechanical Properties, second ed. Gordon and Breach Science Publishers Inc., New York.

Moore, D., Sanei, A., Van Hecke, E., \& Bouvier, J. M. (1990). Effect of ingredients on physical/structural $\begin{array}{lllllll}\text { properties of } & \text { extrudates. } & J & \text { Food } & \text { Sci., } & 55(5), & 1383-1387 .\end{array}$ http://dx.doi.org/10.1111/j.1365-2621.1990.tb03942.x

Naylor, R. L., Goldburg, R. J., Primavera, J. H., Kautsky, N., Beveridge, M. C. M., Clay, J., ... Troell, M. (2000). Effect of aquaculture on world fish supplies. Nature, 405, 1017-1024.

Nielsen, E. (1976). Whole seed processing by extrusion cooking. J. Am. Oil Chem. Soc., 53(6), 305-309. http://dx.doi.org/10.1007/BF02605709

NRC (National Research Council). (1993). Nutrient Requirements of Fish. Washington D. C.: National Academy Press. Retrieved from http://www.nap.edu/openbook.php?record_id=2115\&page=1\#

O'Brien, J. O., \& Morrisey, P. A. (1989). Nutritional and toxicological aspects of the Maillard browning reaction in food. Crit. Rev. Food Sci. Nutr., 28, 211-248.

Opstvedt, J., Nygard, E., Samuelsen, T. A., Venturini, G., Luzzana, U., \& Mundheim, H. (2003). Effect on Protein digestibility of different processing conditions in the production of fish meal and fish feed. $J$. Sci. Food Agr., 83, 775-782.

Papatryphon, E., Howell, R. A., \& Soares, J. H. (1999). Growth and mineral absorption by striped bass Morone saxatilis fed a plant feedstuff based diet supplemented with phytase. J. World Aquacult. Soc., 30(2), 161-173. http://dx.doi.org/10.1111/j.1749-7345.1999.tb00863.x

Phillips, A. M. (1949). Fisheries Research Bulletin No.13. Cortland Hatchery Report No. 18. Cortland, New York, USA.

Phillips, A. M., Hammer, G. L., Edwards, J. P., \& Hosking, H. F. (1964). Dry concentrates as complete trout foods for growth and egg production. Prog Fish-Cult., 26, 155-159.

Pritchard, G. I. (1976). Structured aquaculture development with a Canadian perspective. J. Fish. Res. Bd. Can., $33,855-870$.

RFA (Renewable Fuels Association). (2010). DDGs feed, livestock, and our economy. Export Exchange 2010. Retrieved http://www.ethanolrfa.org/exchange/entry/ddgs-feed-livestock-and-our-economy-export-exchange-2010/

Riaz, M. N. (2000). Extruders in Food Applications (pp. 1-2, 19, 27, 82-85). Lancaster, PA, USA: Technomic Publishing Co, Inc.

Robinson, E. H. (1991). Improvement of cottonseed meal protein with supplemental lysine in feeds for channel catfish. J. Appl. Aquacult., 1, 1-14.

Robinson, E. H., \& Li, M. H. (2008). Replacement of soybean meal in channel catfish, Ictalurus punctatus, diets with cottonseed meal and distiller's dried grains with solubles. J. World Aquacult. Soc., 39, 521-527. http://dx.doi.org/10.1111/j.1749-7345.2008.00190.x 
Robinson, P. H., Karges, K., \& Gibson, M. L. (2008). Nutritional evaluation of four co product feedstuffs from the motor fuel ethanol distillation industry in the Midwestern USA. J. Anim. Feed Sci. Technol., 146, 345-352.

Rodehutscord, M., \& Pfeffer, E. (1995). Effects of supplemental microbial phytase on phosphorus digestibility and utilization in rainbow trout (Oncorhynchus mykiss). Water Sci. Technol., 31(10), 141-147.

Rolfe, L. A., Huff, H. E., \& Hsieh, F. (2000). The effect of processing conditions on the quality of extruded catfish feed. Transactions of the ASAE, 43, 1737-1743.

Rolfe, L. A., Huff, H. E., \& Hsieh, F. (2001). Effects of particle size and processing variables on the properties of an extruded catfish feed. J. Aquat. Food Prod. Technol., 10(3), 21-33. http://dx.doi.org/10.1300/J030v10n03_03

Romarheim, O. H., Aslaksen, M. A., Storebakken, T., Krogdahl, A. S., \& Skrede, A. (2005). Effect of extrusion on trypsin inhibitor activity and nutrient digestibility of diets based on fish meal, soybean meal and white flakes. Arch. Anim. Nutr., 59, 365-375.

Rosentrater, K. A., \& Tulbek, M. (2010). Extrusion of aquafeeds containing corn distillers dried grains with solubles (DDGS) for Nile tilapia. Aquaculture America, March 1-5, San Diego, California.

Rosentrater, K. A., \& Muthukumarappan, K. (2006). Corn ethanol coproducts: Generation properties, and future prospects. Int. Sugar J., 108, 648-657.

Rosentrater, K. A., Muthukumarappan, K., \& Kannadhason, S. (2009). Effects of ingredients and extrusion parameters on aquafeeds containing DDGS and potato starch. Journal of Aquaculture Feed Science and Nutrition, 1, 22-38.

Rosentrater, K. A., Richard, T. L., Bern, C. J., \& Flores, R. A. (2005). Small scale extrusion of corn masa byproducts. Cereal Chem., 82, 436-446.

Rout. R. K.(1997). Studies on extrusion cooking in relation to shrimp feed processing. Ph.D. Thesis, Indian Institute of Technology, Kharagpur, India.

Rumsey, G. L., Hughes, S. G., \& Winfree, R. A. (1993). Chemical and nutritional evaluation of soya protein preparations as primary nitrogen sources for rainbow trout (Oncorhynchus mykiss). Anim. Feed Sci. Technol., 40, 135-151. http://dx.doi.org/10.1016/0377-8401(93)90152-A

Sablani S. S., Baik O. D., \& Marcotte M. (2002). Neural networks for predicting thermal conductivity of bakery products. J. Food Eng., 52, 299-304.

Samocha, T. M., Davis, D. A., Saoud, I. P., \& DeBault, K. (2004). Substitution of fish meal by co extruded soybean poultry by-product meal in practical diets for the Pacific white shrimp, Litopenaeus vannamei. Aquaculture, 231, 197-203.

Sandra, H. P. F., \& Jose, A. G. A. (1993). Effect of phospholipid on protein structure and solubility in the extrusion of lung proteins. Food Chem., 47,111-119. http://dx.doi.org/10.1016/0308-8146(93)90230-D

Sathe, S. K., Deshpande, S. S., \& Salunke, D. K. (1982). Functional properties of lupin seed (Lupinus mirabilis) protein and protein concentrates. J. Food Sci., 47, 491-497.

Saunders, J. A., \& Rosentrater, K. A. (2009). Properties of solvent-extracted low-oil corn distillers dried grains with solubles. Biomass Bioenergy, 33, 1486-1490.

Schaeffer, T. W., Brown, M. L., \& Rosentrater, K. L. (2011). Effects of dietary distillers dried grains with solubles and soybean meal on extruded pellet characteristics and growth responses of juvenile yellow perch. N. Am. J. Aquacult., 73, 270-278. http://dx.doi.org/10.1080/15222055.2011.593461

Schaeffer, T. W., Brown, M. L., \& Rosentrater, K. A. (2009). Performance characteristics of Nile tilapia (Oreochromis niloticus) fed diets containing graded levels of fuel-based distillers dried grains with solubles. Journal of Aquaculture Feed Science and Nutrition, 1, 78-83.

Shagun, J. F., \& Harper, J. M. (1980). Effect of screw restrictions on the performance of an autogenous extruder. J. Food Process Eng., 3, 199-216.

Shapawi, R., Ng, W. K., \& Mustafa, S. (2007). Replacement of fish meal with poultry by-product meal in diets formulated for the humpback grouper. Cromileptes altivelis. Aquaculture, 273, 118-226.

Shiau, S. Y., Chuang, J. L., \& Sun, G. L. (1987). Inclusion of soybean meal in tilapia (Oreochromis niloticus $\times$ O. aureus) diets at two protein levels. Aquaculture, 65, 251-261. 
Shurson, G., \& Noll, S. (2005). Feed alternative uses for DDGS. Department of Animal Science, University of Minnesota, St. Paul, MN. Presented at the conference "Energy from Agriculture: New Technologies, Innovative Programs, and Success Stories," St. Louis, MO (December, 2005). Retrieved from http://ageconsearch.umn.edu/bitstream/7623/1/cp05sh01.pdf

Singh, V., Johnston, D. B., Naidu, K., Rausch, K. D., Belyea, R. L., \& Tumbleson, M. E. (2005). Comparison of modified dry-grind corn processes for fermentation characteristics and HPDDG composition. Cereal Chem., 82, 187-190.

Sokhey, A. S., Kollengode, A. N., \& Hanna, M. A. (1994). Screw configuration effects on corn starch expansion during extrusion. J. Food Sci., 59, 895-899. http://dx.doi.org/10.1111/j.1365-2621.1994.tb08152.x

Spiehs, M. J., Whitney, M. H., \& Shurson, G. C. (2002). Nutrient data base for distillers dried grains with solubles produced from new generation ethanol plants in Minnesota and South Dakota. J. Anim. Sci., 80, 2639-2645.

Spiehs, M. J., Whitney, M. H., \& Shurson, G. C. (2002). Nutrient database for distiller's dried grains with solubles produced from new ethanol plants in Minnesota and South Dakota. J. Anim. Sci., 80, 2639-2645.

Steven C., \& Louis A. H. (2002). Understanding fish nutrition, feeds, and feeding. Virginia Cooperative Extension. Retrieved from http://pubs.ext.vt.edu/420/420-256/420-256.html

Storebakken, T., Baeverfjord, G., Skrede, A., Olli, J. J., \& Berge, G. M. (2004). Bacterial protein grown on natural gas in diets for Atlantic salmon, Salmo salar, in freshwater. Aquaculture, 241, 413-425.

Storebakken, T., Shearer, K. D., \& Roem, A. J. (1998). Availability of protein, phosphorus and other elements in fish meal, soy-protein concentrate and phytase-treated soy-protein concentrate-based diets to Atlantic salmon, Salmo salar. Aquaculture, 161(1-4), 365-379.

Sugiura, S. H., Gabaudan, J., Dong, F. M., \& Hardy, R. W. (2001). Dietary microbial phytase supplementation and the utilization of phosphorus, trace minerals and protein by rainbow trout [Oncorhynchus mykiss (Walbaum)] fed soybean meal-based diets. Aquac. Res., 32(7), 583-592.

Thomas, M., Paul, T. H. J. H., Ton, V. V., Dick, J. V. Z., \& Antonius, F. B. V. P. (1999). Effect of process conditions during expander processing and pelleting on starch modification and pellet quality of tapioca. $J$. Sci. Food Agric., 79, 1481-1494.

Tidwell, J. H., Webster, C. D., \& Yancey, D. H. (1990). Evaluation of distillers grains with solubles in prepared channel catfish diets. Trans. Ky. Acad. Sci., 51, 135-138.

Tumuluru, J. S., \& Sokhansanj, S. (2008). Optimization of aqua feed pellet properties using genetic algorithm. American Society of Agricultural and Biological Engineers. 2008 ASABE Annual International Meeting. Providence, Rhode Island.

University of Minnesota, Department of Animal Science. (2008). Overview. Distillers dried grains with solubles. Distillers Grains By-Products in Livestock and Poultry Feeds. Retrieved from http://www.ddgs.umn.edu/overview.htm

USDA (United States Department of Agriculture). (2010). Market issues and prospects for U.S. distillers' grains: supply, use, and price relationships. Economic Research Service. Retrieved from http://ethanolrfa.3cdn.net/9365a78e80c2083907_48m6b9ogq.pdf

USGC (US Grains Council). (2008). Use of DDGS in aquaculture diets. DDGS User Handbook. Retrieved from http://www.grains.org/ grains27/images/stories/DDGS_user_handbook/DDGS\%20Handbook\%20FULL.pd $\mathrm{f}$

Vens-Cappell, B. (1984). The effects of extrusion and pelleting of feed for trout on the digestibility of protein, amino acids and energy and on feed conversion. Aquacult. Eng., 3, 71-89.

Vielma, J., Lall, S. P., Koskela, J., Schöner, F. J., \& Mattila, P. (1998). Effects of dietary phytase and cholecalciferol on phosphorus bioavailability in rainbow trout (Oncorhynchus mykiss). Aquaculture, 163(3-4), 309-323.

Vielma, J., Mäkinen, T., Ekholm, P., \& Koskela, J. (2000). Influence of dietary soy and phytase levels on performance and body composition of large rainbow trout (Oncorhynchus mykiss) and algal availability of phosphorus load. Aquaculture, 183(3-4), 349-362.

Watanabe, T. (2002). Strategies for further development of aquatic feeds. Fisheries Sci., 68, 242-252. 
Webster, C. D., Tiu, L. G., Margan, A. M., \& Gannam, A. (1999). Effect of partial and total replacement of fishmeal on growth and body composition of sunshine bass, Morone chrysops X M. saxatilis, fed practical diets. J. World Aquacult. Soc., 30, 443-453.

Webster, C. D., Tidwell, J. H., \& Yancey, D. H. (1991). Evaluation of distillers grains with solubles as a protein source in diets for channel catfish. Aquaculture, 96, 179-190.

Willix J., Lovatt S. J., \& Amos N. D. (1998). Additional thermal conductivity values of foods measured by a guarded hot plate. J. Food Eng., 37, 159-174.

Wood, J. (1995). Selecting equipment for producing farm-made aquafeeds. In M. B. New, A. G. J. Tacon, \& I. Csavas (Eds), Farm-Made Aquafeeds (pp. 135-147). FAO Fisheries Technical Paper No.343, FAO, Rome.

Wu, Y. V., Rostagi, R. R., Sessa, D. J., \& Brown, P. B. (1996). Effects of diets containing various levels of protein and ethanol coproducts from corn on growth of tilapia fry. J. Agric. Food Chem., 44(6), 1491-1493.

Zhou, P., Davis, D., Lim, C. E., Akshoy, M., Paz, P., \& Roy, L. A. (2010). Pond demonstration of production diets using high levels of distiller's dried grains with solubles with or without lysine supplementation for channel catfish. N. Am. J. Aquacult., 72, 361-367. 